Portland State University

PDXScholar

1971

\title{
Post-divorce visitation of minor children; development of a questionnaire
}

\author{
Viola Cotter \\ Portland State University \\ Lorraine Goldenberg \\ Portland State University \\ Terry McGill \\ Portland State University
}

Follow this and additional works at: https://pdxscholar.library.pdx.edu/open_access_etds

Part of the Child Psychology Commons, Family, Life Course, and Society Commons, and the Social Work Commons

Let us know how access to this document benefits you.

\section{Recommended Citation}

Cotter, Viola; Goldenberg, Lorraine; and McGill, Terry, "Post-divorce visitation of minor children; development of a questionnaire" (1971). Dissertations and Theses. Paper 1448.

https://doi.org/10.15760/etd.1447

This Thesis is brought to you for free and open access. It has been accepted for inclusion in Dissertations and Theses by an authorized administrator of PDXScholar. Please contact us if we can make this document more accessible: pdxscholar@pdx.edu. 


\title{
POST-DIVORCE VISITATION OF MINOR CHILDREN : DEVELOPMENT OF A QUESTIONNAIRE
}

\author{
Prepared By \\ Viola Cotter \\ Lorraine Goldenberg \\ Terry McGill
}

Soclal Work 501, 502 and 503

Research Pract1cum

\author{
D1rected By \\ Vincent Glaudin, Ph. D.
}

Portland State Unlversity

May 15, 1971 


\section{ACKNOWLEDGMENTS}

Special appreciation is expressed to Judge Jean L. Lewis whose concern for the minor children of divorced parents stimulated this study. Thanks are warmly extended to Mr. Richard Collins and Mr. Donald Welch who provided the research team with the resources of the Famlly Services Department. Mrs. Ruth Strejc and the secretarlal staff of that department contributed their invaluable ald by helping with the malling of the questionnalres. The research team also wishes to acknowledge the speclal contributions of Dr. Arthur Emlen, who provided resource material and offered his expertise in considering the methodological questions which grew out of this pllot project. 
TABLE OF CONTENTS

I. Introduction

+ A. Divorce: The Routine Crisis ........... I

A B. Oregon Law ........................ 3

C. Multnomah County $\ldots \ldots \ldots \ldots \ldots \ldots \ldots \ldots$

D. Custody and visiting $\ldots \ldots \ldots \ldots \ldots \ldots \ldots$

+ E. Research on Post-Divorce V1siting of

Minor Ch1ldren ................. 9

F. Statement of Purpose $\ldots \ldots \ldots \ldots \ldots \ldots \ldots, 12$

II. Method

A. Overall Research Strategy ........... 14

B. Questionnalre Construction ............ 14

C. Questionna1re Respondent Sample ........ 16

1) Selection and Approach to Subjects ................. 16

2) Demograph1c Character1st1cs ....... 18

D. Interview Sub-Sample $\ldots \ldots \ldots \ldots \ldots \ldots . . .20$

1) Selection and Approach to Subjects $\ldots \ldots \ldots \ldots \ldots \ldots \ldots 20$

2) Demograph1c Characteristics

of Interview Sample .......... 23

III. Results

A. Quest1onna1re Content ............. 24 
† 1) Parent's Relationship .......... 24

f 2) Discussion About V1siting ....... 25

† 3) Custody and Care .............. 26

+ 4) V1siting and Expectancies ....... 27

B. Rellab1l1ty of Questionnaire Items ..... 30

1) Source of Varlance ........... 30

2) Scoring Agreement Criteria ...... 31

3) Percentage of Agreement ....... 32

C. Sample Representativeness ........... 35

- 1) Minor Ch1ld Questionnaire Ma11

Sample ................ 35

× 2) Interview Sub-Sample ......... 37

IV. Discussion $\ldots \ldots \ldots \ldots \ldots \ldots \ldots \ldots \ldots \ldots \ldots \ldots$

A. Visiting .................... 40

B. Questionna1re Rellab1lity .......... 42

C. Sampling Representativeness .......... 44

D. A Dilemma of Preventive Mental Health .... 47

v. B1bllography $\ldots \ldots \ldots \ldots \ldots \ldots \ldots \ldots \ldots \ldots \ldots, 51$

VI. Appendixes $\ldots \ldots \ldots \ldots \ldots \ldots \ldots \ldots \ldots \ldots \ldots \ldots \ldots$

A. Questionna1res and Results

1. Questionnalre and Results From

the Malled Questionnalre For

the Mother of a Minor Ch1ld .... 54 
2. Questionna1re and Results From the Malled Questionnalre For the Father of a Minor Child .... 67

B. Guidelines For Contacts W1th Subjects

1. Letter From Judge Jean L. Lew1s ... 80

2. Follow-Up Phone Call .......... 82

3. Follow-Up Letter ............ 83

4. Making Interview Appointment ..... 84

5. Beginning of Interview ........ 85

c. Number, Percentage, and Correlation of

Response Agreement Between Malled-In

Questionnaires and the 30 Interviews ... 87 


\section{LIST OF TABLES}

TABLE

PAGE

1. Mean Demographic Characteristics of

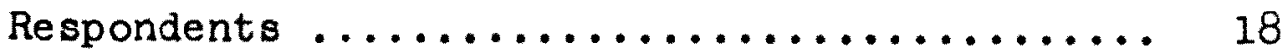

2. Attrition Pattern From Questionnaire

Respondents to Interview Subjects ......... 21

3. Demographic Characteristics of

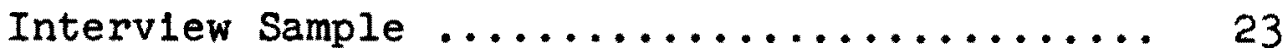

4. Percentage of Agreement for Factual vs.

Feeling or Opinion Items $\ldots \ldots \ldots . \ldots \ldots$

5. Percentage of Agreement for Items in

Content Categories .................... 34

6. Age, Years Married, and Number of

Children of Oregon Samples ............ 36

7. Educational Level of Questionna1re

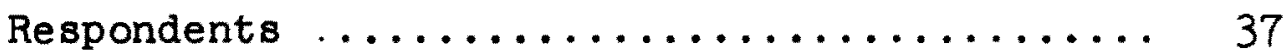

8. Age, Years Married, and Number of

Children of Ma1l Sample and Interview

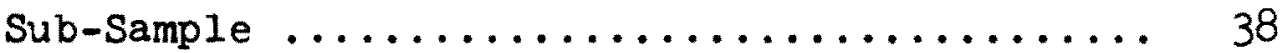

9. Educational Level of Ma1l Sample and

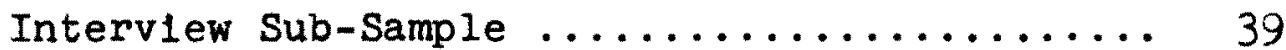

10. Size of Family ....................... 49

11. Number of Children by Age Group ............ 49 


\section{INTRODUCTION}

A. Divorce: The Routine Crisis

The dissolution of families by divorce has become extremely common. It attracts little attention as an acute mental health stress warranting vigorous methods of crisis intervention or preventive psychlatry concerning the minor chlldren involved as third parties. Not only are divorces exceedingly common in contemporary soclety, but the rate of divorce per thousand population has been increasing in Oregon. Associated with this trend is the high percentage of broken homes which include minor chlldren. Urban Multnomah County, for instance, recorded more than one-third of the divorces granted in 1969 as cases with chlldren under age 18; rural Benton County, more than one-half. Since there are approximately two minor chlldren per broken family, an estimated 3000 dependent children will feel the Impact of divorces granted this year in Multnomah County. (Bureau of V1tal Statistics, State of Oregon, 1969.)

Certainly, there is no need to belabor the point that the breakdown of a family unit is painful for everyone in 1t, especlally chlldren in the early stages of development. It has been pointed out (Schwartz, 1968) that family agency counseling is routinely confronted by problems of divorce and chlldren from multiple marriages. Furthermore, Codding- 
ton (1970) found that professional people who deal with children rank divorce of parents as one of the most traumatic events that may distort normal development from the pre-school perlod through the mid-teens. It should be kept In mind that the impact of divorce per se is difficult to assess but it is correlated with a wide range of developmental maladjustments. A number of studies have shown that the nature of personal maladjustment in children whose parents divorce is complex and variable. (Locke, 1951; Goode, 1956; Landis, 1960; Glueck and Glueck, 1962; Rosenberg, 1965; Buss, 1966; Hunt, 1967.) Locally, it has been reported that about half the referrals for juvenile delinquency are children who are not living in a complete family unit. (Multnomah County Juvenile Dept., 1969.)

As a rule throughout the nation, our legal system inadvertently aggravates the divorce crisis rather than serving as an entre for both symptomatic treatment and secondary prevention ${ }^{1}$ of behavior disorders. It has been pointed out many times that the adversary system is inappropriate in discharging the court's responsibilities to troubled families. The system of establishing "fault" aggravates the parents' vendetta and further impairs their capacity to rear children. Most recently, Wadlington (1969) has detalled the old

$I_{\text {Gerald Caplan, Principles of Preventive Psychiatry }}$ (New York: Basic Books, 1964).

Caplan refers to three public health concepts regarding prevention--primary, secondary and tertiary prevention. 
story of how negotiations concerning custody and visitation are sandwiched between the attorney's efforts to secure the best possible material settlement for his client. In discharging h1s ethical responsibllity, to press h1s cllent's case along with the economic constralnts of his professional role, it would be an extraordinary attorney indeed who could function effectively as a family counselor. Instead, the minor child is usually not unlike chattel in the bargaining "dividing the spolls." (Leslie, 1967.) Legal reforms such as "no fault" divorce decrees, establishment of "fam1ly courts," and having separate legal counsel for minor children are now being advocated. (Hansen \&oldberg, 1967; Wadlington, 1969.)

\section{B. Oregon Law}

Oregon's 1971 Leg1slature, now in session, is considering a number of reforms. It has enacted a "no fault" divorce law similar to those in Iowa and California. Moreover, the Legislature 1s welghing the establishment of a centralized administrative unit intended to strengthen resources for chlldren. At the present time, however, all the problems of the adversary system exist in Oregon's law. The vast majority of minor chlldren experiencing the crisis of their parents' divorce probably recelve no special services. The usual system of private attorneys struggling 
with custody-visitation problems, in the context of a financlal settlement, 1 s the mule. Since $80 \%$ to $90 \%$ of divorce decrees are default cases, they are processed by the court in just a few minutes. Ordinarily the trial judge will have time only to insure that there is some provision for child support and "reasonable visitation." Otherwise, the trial judge's time is consumed by the hard-core minority of cases which are bitter custody battles and hostile modifications of visiting arrangements. In these cases there is often a thorough examination of the families although solutions to date have been hampered by the adversary nature of the proceedings.

There is a great disparity between the practical problem the trial judge faces in dealing with hundreds of divorces and the great responsibility the law places upon him for the welfare of minor children. ORS 107.100 "Provisions of Decree of Dlvorce or Annulment" clearly states that the court shall consider the "best interests" of the child in determining custody and the mother per se shall not be given preference. Although it is customary to grant the noncustodial parent "reasonable" arrangements for visiting his chlldren, this has been established by case law rather than by statute. (Hammersley, 1970.) There is no question that the trial judge has broad responsibliltles and broad powers in looking after the welfare of a minor child as third party 
to a divorce action. Furthermore, according to the oregon Supreme Court (Tingen vs. Tingen, 1968) he 1s admonlshed to consider a complex configuration of no less than elght major factors in reaching his opinion rather than relying on any simplistic tradition.

\section{Multnomah County}

Oregon's highly urbanized center has a speclal resource to help cope with the problems of divorce, the Family Services Department of the Multnomah County C1rcult Court. Its experlenced counselors provide both conclilation counseling (prior to divorce) and custody-visitation consultations. Historically a high priority was given to conclilation counseling which might help head off impulsive, unwarranted divorce actions. Typlcally a husband petitions the court for conclilation counseling after his wife has taken some inftial step in the divorce process. She may be required to participate in brief counseling before the court will act on her intention to dissolve the marriage. This is a unique variation on the widespread use of "marriage counselIng" provided by pastors, social workers, psychiatrists, psychologists and others in the community.

Over the years, the Family Services Department has gradually developed an increasing caseload of "custody counseling," focused primarily on issues of custody and visit- 
Ing arrangements. (Family Services Department Annual Report, 1969.) Th1s might properly be called "divorce counseling" as well in that it attempts to help marriage partners separate with less rancor and better able to carry out their parenting roles. Here there is an attempt to have parents particlpate in decision-making regarding how they w1ll function as parents to their minor chlldren, rather than engaging in bitter court battles or belng subject to arbitrary judiclal rulings. In some instances, the c1rcult court may require time-11mited custody-visiting counseling with the understanding that an agreement must be reached by the parents or mules will be dictated to the parents.

Although Multnomah County is fortunate in belng a step closer to a problem-solving "family court," only a selected segment of cases has an opportunity to benefit from these sophlsticated extra services. These are the cases where a party to the legal conflict contests what the spouse or exspouse is doing or intends to do. The routine divorce in Multnomah County, as elsewhere, is handled as a default case whether there are minor chlldren involved or not. This means that the most common type of family dissolution takes place mechanlcally with no speclal services provided by the State of Oregon elther to gulde the separating parents or to directly help their minor children cope with this 1088. 
D. Custody and Visiting

Although 1t is agreed that the "best interests" of the minor child shall have the highest priority when a family 1s dismupted by divorce, there is a notable lack of sclentific knowledge about which custody and visiting arrangement w11l best serve the child's development. Quite apart from the value 18sue about what is "good for the ch1ld," there is no prediction equation for the court to welgh the data on the ch1ld's behalf. Even if these data were rellable--rather than ranging from demographic facts through expert opinion to blased anecdotes--there are no f1rmly established correlations relating these "facts" to outcome criteria. Nevertheless, the court 18 expected to consider the following factors in rendering a sound decision:

1) The conduct of the parties; 2) the moral, emotional, and physical fitness of the parties; 3) the comparative physical environments; 4) the emotional ties of the child to other family members; 5) the interest of the parties in, and attitude toward, the child; 6) the age, sex and health of the child; 7) the desirability of continuing an existing relationship and environment; and 8) the preference of the child. (Tingen v8. Tingen, 1968.)

The custody arrangement not only must consider which parent has foremost responsibllity for the chlld's day-today care and financlal basis for child support, but it must come to grips with the non-custodial parent's role. Usually the court defines this secondary parenting role as "reason- 
able visitation." Again the trial judge would be hard pressed to have a basis in fact for his recommendations or declsions concerning visiting in the average case. Behavloral sclentlsts have not provided a foundation of databased conclusions upon which the court can bulld. Because of thls lack, counselors would be w1se to be humble and open-minded in providing guldance about visiting. (Griffith, Hack, Murphy, Welman, W1lllams, Van Lydegraf, \& Glaudin, 1970.)

What is avallable in the 11terature, concerning the relationship of a dependent child to h1s non-custodial parent, is largely a matter of conjecture and clinical opinion. Usually the absentee father 1s urged to maintain a visiting relationship as part of being a responsible parent, modulated by the practical considerations of the chlld's developmental stage. (Grollman, 1969; Hansen \& Goldberg, 1967; Despert, 1962.) Much of this guldance has a moralistic ring lncluding a cataloguing of the "sins" of divorcing parents. (Pollack, 1967.) Even the progressive family court 1s in danger of assuming that 1ts list of "shoulds" Inevitably serves the child's welfare. (Hansen \& Goldberg, 1967.) In contrast, Steinzor (1969) contends that the parents need "heartfelt confrontation" which produces a genuine "emotional divorce." His experience leads him to belleve that parents are capable of only the most superfi- 
clal cooperation in caring for a dependent child after divorce. In any event, the typical non-custodial father appears to fade out of the plcture rapidly both in terms of visiting and maintaining his child support. (Eckhardt, 1968.) The entire matter is complicated by remarriages (Schwartz, 1968) with some findings suggesting that this normalizes the life of the fatherless child (Goode, 1956), while other data show that the custodial mother's remarrlage infures the self-esteem of at least some children. (Rosenberg, 1965.)

E. Research on Post-Divorce Visiting of Minor Children There has been almost no published research specifically pertalning to the nature of the visiting relationship between the non-custodial parent and h1s minor child or 1ts bearing on the child's best interests. As indicated in section $D$ above, most data is anecdotal, unsystematic or tangent1al to th1s area. However, Goode (1956) systemat1cally interviewed more than 400 divorced mothers of minor children on many toplcs and included several questions about the frequency and quality of visiting. A little more than half of the mothers "permitted" visiting at "any time" or "weekly." This was classifled as high frequency visiting. The median group of mothers was satisfled with visiting frequency, whether it was high or low, but one-fifth desired 
the fathers to see more of the chlldren. Goode concluded that the children seemed to provide a vehicle for the continuing struggle between the divorced parents, including the 1ssue of support payment. It was h1s interpretation that the child benefited most when the mother remarried so that the youngster was integrated in a new family unit. It is important, however, to keep in mind that Goode's information all came from the perceptions of the mothers, including those that had remarried.

Paget and Kern (1960) carried out a malled survey whlch offered social work services to divorced individuals. One of their three categories was services avallable to chlldren. Of 195 respondents, the child-centered category ranked the lowest in frequency of requests. In1tialiy 22\% of respondents requested interviews concerning their children but only about half of these parents actually followed through. Five per cent of the total pool of respondents came in to the agency and talked about problems relating to visiting. These were mothers who complained that the child's contacts with the non-custodial father were destructive.

In a recent Oregon study (Griffith, et al, 1970), visiting was the central post-divorce area wh1ch was examined. Th1s research, carried out in Multnomah and Benton Countles, reached the conclusion that it was not feasible to 
contact a representative sample of divorced parents through telephone listings or old addresses avallable at the time of divorce one to five years earlier. Nevertheless, twentyfour Interviews focused on visiting problems were carried out on a non-representative sample of divorced parents. This interviewing provided the ground work necessary to move from broad concerns toward a highly structured questionnalre or interview schedule. Findings from these original looselystructured interviews suggested that "frequent" visiting meant "once-a-week" for recently divorced parents and "twicea-month" for those divorced several years. Th1s local study also concluded that frequent visiting was not necessarily associated with child-centered parental behavior. In a number of cases the high contact group was involved in vindictive struggles, arguments about child support, or reconclliation efforts. Those parents divorced for three to flve years were more 11 kely to have less frequent visiting but a better quality of visiting. In the blased sample interviewed, these older parents, who were also divorced longer, were not engaged in the old bltter conflicts which had racked the marriage. Another important tentative conclusion of this preliminary investigation was that the children themselves, usually by age elght, played a significant role in the decisions influencing the visiting pattern. 
F. Statement of Purpose

The present descriptive study was broadly concerned about divorces which have an impact on minor children. It was intended to bulld on the previous research of Griffith, Hack, Murphy, Wieman, Williams, Van Lydegraf \& Glaudin (1970) in describing the relationships between parents and children after divorce. It was the objective of the present research team to come closer to the goal of selecting a representative sample of divorced parents than was possible previously. Moreover, an attempt was made to develop $q$ highly structured questionnaire and interview schedule growing out of the earlier experlence with semi-structured interviews.

Data to be collected in the present study were to be much more specific and much less impressionistic. Although 1t was considered desirable to obtain a general plcture of the family dissolution as early in the divorce process as possible, special consideration was given to issues pertaining to the visiting relationship of the minor child and the non-custodial parent. In addition, the present research not only intended to gather descriptive content about divorcing parents and their children, but to give primary emphasis to assessing the reliability of the findings. To recapitulate, the purpose of this study focused on the following immediate goals: 
1) To sample a representative group of divorcing parents of minor chlldren early in the divorce process.

2) To construct a highly-structured questionnalre whlch would describe divorcing parents, their relationship, attitudes, visiting arrangements and the adjustment of the minor chlidren.

3) To determine the rellab1lity of data gathered by means of a malled questionnalre which taps this content. 


\section{METHOD}

\section{A. Overall Research Strategy}

The baslc strategy of the study was to compare responses to a malled questionnalre completed by divorcing parents w1th the responses of a sub-sample of parents who were interviewed. The malled questionnalre, emphasizing description of the visiting relationship of a minor child and a non-custodial parent, was distributed during a onemonth perlod to couples who filed for divorce at the Multnomah County Circuit Court. Questionnaires returned by these subjects provided the data for describing familles at this stage of dissolution. An estimate of the rellability of each questionnaire 1tem was made in terms of per cent of agreement between a parent's malled reply and his interview answer. ${ }^{2}$ The interview data were collected without interviewer knowledge of the previously volunteered information. The respondent was informed of this fact to maximize his freedom to respond in the interview without straining artificlally toward consistency.

\section{B. Questionna1re Construction}

A 59 1tem Minor Child Questionnalre was constructed with almost all questions coded in a multiple choice fashion

${ }^{2}$ Since the returned questionnaires included 27 complete couples in the sample, it will be possible to make an add1tional estimate of reliablity for some 1tems. This analysis was not completed for the present report. 
(Append1x A). Many of the questions were maintained in their present form in order to be consistent with previous studies. The Minor Child Questionnalre consisted of the following broad categorles:

1) Demographic - Items 1 to 13 described the subject in terms of age, race, occupation, education, and income. The questions were based on earlier survey carried out by the Family Services Department. (Karr, 1964.)

2) Parents' Relationship - Items 14 to 33 deplcted the marriage relationship, separation, attitudes and stability of the partners. These items were drawn from a varlety of sources. (Goode, 1956; National Center for Health Statistics; Karr, 1964; Gr1ffith, et al, 1970.)

3) V1s1ting Arrangements - Items 34 to 58 focused on custody and visiting with an attempt to reveal both current behavior and expectancles. The section included attitudes, practical deta1ls, projected concerns, and the role that the court should play. By necessity, almost all of these questions were new with the exception of the few avallable from Goode's research. 
4) Children's Identification - The last item of the questionnalre identifles all the chlldren from the present marriage by name, sex and age.

\section{Questionna1re Respondent Sample}

1) Selection and Approach to Subjects: The original pool of Individuals consisted of all those who flled for divorce at the Multnomah County Courthouse between February 10th and March 10, 1971. These people were l1sted the day of flling in the fee book; however, it was usually one week later before a divorce flle was sufflclently complete to provide the necessary information for sample selection. To be selected from the total pool, the divorce file information had to meet the following criterla:

a. The family must include at least one child under the age of 18 .

b. There had to be at least one address avallable for a parent.

Questionnalres were malled individually to the mother and father if just one address was given. In some cases there were two addresses, one of which may have been a place of business. Several cases permitted malling to just one party to the divorce. There were also instances where divorcing parents with minor chlldren showed no address so those famllies were excluded from the sample. As soon as it was determined that an individual was a divorcing parent 
with a minor child, he or she was malled a Minor Ch1ld Questionnalre with an explanatory letter from Judge Jean Lewis (Append1x BI).

A total of 281 Minor Ch1ld Questionnalres were malled to subjects meeting the criterla. Those that recelved the questionnaires did so within two weeks of the original f1l1ng. Twelve cases were ellminated from the sample because the parties no longer resided at the listed address. S1x other cases were eliminated because reconclliation had taken place. Therefore, 263 subjects meeting the criterla may be assumed to have recelved the Minor Child Questionnalre. If the questionnalre was not returned within two weeks, a follow-up procedure was carried out conslsting of telephone calls (Append1x B2) and letters (Append1x B3). Telephone numbers were obtalned for 37 non-respondent subjects and 21 of them were reached after a minimum of three calls. This group included the $s 1 x$ reconclled couples; of the remalning 15, elght subsequently returned the questionnalres. of 136 follow-up letters sent to subjects with no telephone listing or those living out of Portland, only five became legitimate respondents. Finally, 114 Minor Chlld Questionnalres were returned representing approximately a $44 \%$ respondent rate. of these, 108 were returned by Apr11 15, 1971 and were used as the $\mathrm{N}$ for evaluating almost all of the results. 
2) Demograph1c Character1st1cs: The 108 respondents who completed the malled Minor Ch1ld Questionnaire colncldentally fell into equal numbers of mothers and fathers. Although the range of respondent characteriatics was very broad, the average parent was in his early 30's, had been marrled about ten years, had two chlldren and had completed high school as seen in Table 1 .

TABLE 1

MEAN DEMOGRAPHIC CHARACTERISTICS OF RESPONDENTS

\begin{tabular}{lcc}
\hline & $\begin{array}{c}\text { Mothers } \\
\mathrm{N}=54\end{array}$ & $\begin{array}{c}\text { Fathers } \\
\mathrm{N}=54\end{array}$ \\
\hline Age & 30.67 & 33.18 \\
Length of Marriage & 9.77 & 10.51 \\
Number of Ch1ldren & 2.09 & 2.09 \\
Years of Education & 12.5 & 12.5 \\
\hline
\end{tabular}

a. Mother Respondents: Almost all (96\%) of the respondents were Caucasian and the majorlty indicated they were Protestants. Typlcally their present marriage took place when they were 20 years old while only a quarter reported a previous marriage. Although more than half (59\%) were employed, they had usually worked for the most recent 
employer less than a year and earned approximately $\$ 2000$ per year. Almost two-thirds of the mother respondents had been separated from thelr husbands for more than a month but about the same percentage sald they had lived in the same residence for at least a year. Half reported that they had been separated before and had discussed divorce with thelr husbands from one to two years prior to filing.

b. Father Respondents: The same 1dentical high percentage of father respondents described themselves as Caucasian (96\%) and again the majorlty stated they were Protestants (56\%). The men had married at age 22 or 23 with only a few (11\%) reporting a previous marriage. Approximately $85 \%$ sald they were employed. Two-thirds revealed that they earned at least $\$ 6,000$ per year. They had usually worked for their present employer less than five years $(60 \%)$. A little more than half of these men (62\%) had been separated from their wife more than a month; almost half (40\%) had been separated before while discussion about divorce had first occurred about a year and a half ago. The 1dentical percentage who sa1d they were separated more than a month also reported they had lived at their present address for less than a year. 
D. Interview Sub-Sample

1) Selection and Approach to Subjects: The interview sub-sample of 30 divorcing parents was drawn from the 54 fathers and the 54 mothers who returned a completed questionnalre. To reduce the varlability of arrangements, only those respondents who fit the pattern of mother-custody of at least one child were cons1dered eligible for an interview. Questionnalres showed that $91 \%$ of the respondents fit into this arrangement. There was the additional practical criterion of selecting only those respondents who live within the Portland Metropolitan Area. Again 91\% of the revised pool met the geographical criterion so that the combined restrictive criteria reduced the potential $N$ from 108 to 88 . These 88 names were divided 1nto three groups with equal sex ratios for the three research interviewers to contact. To reduce experimental bias, the interviewer knew only the name, address, telephone number and mother-custody facts. He had no knowledge of the respondent's answers to questionna1re 1tems.

Since $94 \%$ of the respondents meeting the custody and geographical criterla had provided telephone numbers, this provided the avenue of approach. A minimum of three calls was made to the given numbers and as many as eight were made to some before a case was classifled as "unreachable." When telephone contact was made, the interviewer identified him- 
self, explained the reason for calling and attempted to arrange an appointment time on the Portland State University campus. (Append1x B4.)

Table 2 shows the pattern of attrition from the pool of questionnalre respondents first restricted by selection criterla and then further modifled by the process of making telephone contact or ellclting cooperation.

TABLE 2

ATTRTTION PATTERN FROM QUESTIONNAIRE RESPONDENTS TO INTERVIEW SUBJECTS

\begin{tabular}{lccc}
\hline & Mother & Father & Total \\
\hline & 54 & 54 & 108 \\
Questionna1re Respondents & 44 & 44 & $88 *$ \\
$\begin{array}{c}\text { Rev1sed Pool From Custody } \\
\text { Geographic Criteria }\end{array}$ & 30 & 26 & 56 \\
Telephone Contact Made & 20 & 17 & 37 \\
Appointment Made & 17 & 13 & 30 \\
Interview Completed & & &
\end{tabular}

* Telephone contact revealed that two additional mothers and two additional fathers had reconclled since the questiontwo additional of subjects for interview was actualiy 84 at most.

Appointments were usually made one week to ten days after the questionnalre had been returned and a month to six weeks after the divorce petition had been filed. The $\mathrm{N}$ of

30 interviews was reached on April 28th for subjects filing between February 10th and March loth. Although almost all Interviews were conducted at Portland State University, a few cooperative people who were unable to reach Portland State University, were Interviewed in the1r homes. The purpose and procedure of the interview were carefully explained to each subject as the relationship was structured in the beginning of the contact following a standard outline (Append1x B5). The interviewer attempted to get the best possible grasp of the subject's response to a questionnalre 1tem. This required clarifying and probing in some instances. Each subject was encouraged to elaborate on his situation, to ventilate, to make suggestions about the questionnaire, and to give his opinions about the divorce process. The standard was to gain the kind of information avallable to a clinician using a structured interview schedule. The contact took from a half hour to one hour and 15 minutes. Immediately after the interview, a brief impressionistic summary was written relterating the interviewer's perception of the parent. 
2) Demographic Chracteristics of Interview Sample

TABLE 3

DEMOGRAPHIC CHARACTERISTICS OF INTERVIEW SAMPLE

\begin{tabular}{lcc}
\hline & $\begin{array}{c}\text { Mothers } \\
\mathrm{N}=17\end{array}$ & $\begin{array}{c}\text { Fathers } \\
\mathrm{N}=13\end{array}$ \\
\hline Age & 31.65 & 32.00 \\
Length of Marriage & 10.24 & 10.90 \\
Number of Children & 2.12 & 2.08 \\
Years of Education & 12.88 & 14.15 \\
\hline
\end{tabular}

Typically both the mothers and fathers who were interviewed were employed. Mothers reported earnings at about the $\$ 4000$ to $\$ 6000$ level annually. In keeping with their high average educational level, fathers reported at the $\$ 15,000$ to $\$ 20,000$ level modally. Very few of these mothers (3) or fathers (1) were married before. All of the women and all but one of the men had been separated from their current spouse at least one month. Approximately one-half of the women and one-third of the men had been separated previously. Twelve of the men had lived at their current address less than six months while 14 of the women had lived at their current address at least one year. 


\section{RESULTS 3}

\section{A. Quest1onnaire Content}

1) Parent's Relationshlp: Fourteen per cent of the respondents were still living together three to six weeks after flling for divorce; however, one to three months' separation was the mode. The pattern of the responses showed that the wife typlcally flled for divorce and that she expressed little interest in reconclilation, whereas 44\% of the husbands stated an interest in resuming the marrlage. Three-fourths of the respondents denled that they would marry someone else durlng the year following their divorce. The data showed that nervousness, depression, bad temper, lack of affectional expression, and sex problems were commonly mentioned descriptions of self or spouse. Nevertheless, there was a sex difference in these symptoms or complaints in that alcohol abuse was more likely to be attributed to the fathers, while the subjective possibility of having a "nervous breakdown" was associated more w1th the mothers (54\%). Desplte these indicators of stress, only one respondent in ten admitted that he st1ll wanted the partner to be "pun1shed." Approximately 75\% of respondents denled that they had ever wlshed the spouse to be punlshed. A similar breakdown applied to the rating of current "b1tter-

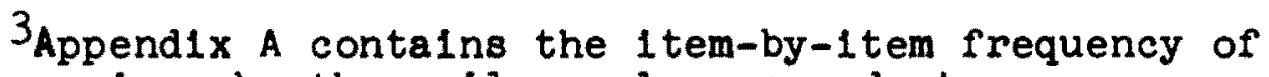
response given by the mall sample respondents. 
ness": about one in ten reported much or very much bitterness while seven out of ten claimed little or no bitterness. About the same proportion of respondents, three out of four, saw the relationship between the divorcing parents as "frtendly" or "businesslike."

2) Discussion About V1siting: Almost no discussion about visiting had taken place between the parents as reported by approximately $25 \%$ of both men and women. Although the typlcal category chosen to describe th1s discussion was "some," about a third of the parents belleved that they had had "much" or "very much" discussion on th1s toplc. The pattern of responses for both fathers and mothers fell into categories suggesting relatively little discussion between parents and chlldren about visiting in that "almost none" was the modal response. Mothers reported somewhat more discussion with their children about visiting the noncustodial parent than fathers did. Although there was a sprinkling of responses indicating that discussion about visiting had taken place with friends, relatives, and counselors, about half the respondents sald that they had discussed visiting with a lawyer. Half the respondents sald they had discussed visiting with no one at all. In addition, three-fourths or more of the respondents expressed no desire to discuss visiting with a professional counselor although there may have been a little more interest on the 
part of fathers (26\%). Th1s is not to say that the same proportion of parents belleved they had a "very clear" agreement about visiting. In fact, three out of four did not report th1s. While about half the respondents thought they had at least a "general agreement," a full third of the parents said they had "no agreement" about visiting.

3) Custody and Care: More than four-fifths of the mothers had the chlldren living with them. Almost all the mothers expected the children to live with them after the divorce was granted, while about a quarter of the fathers reported they expected to gain custody. Only $6 \%$ of the respondent mothers were not in a household with at least one of the minor chlldren; $9 \%$ of the fathers sald they lived with at least one minor chlld and the mother was absent. In supplementing the parents in child care, baby sitters and relat1ves were reported most frequently. Mothers (25\%) commonly sald that the parent was "always at home" to care for the children while one in elght related that the chlldren "look after themselves." Fathers reversed the order of these categorles: $18 \%$ sald the parent was "always at home"; 24\% sa1d the youngsters "look after themselves." According to both mother and father respondent data, a total of only three respondents marked any "falrly regular" use of preschools, nursery schools or day care centers. 
4) V181ting and Expectancies

a. Frequency and Arrangements: About half the respondents reported that the fathers were visiting their chlldren at least once a week. One in flve or s1x visited about once or twice a month. The father respondent sample reported somewhat more contact with the chlldren than mothers described. For example, only $4 \%$ of fathers sald there was no visiting while $16 \%$ of mothers checked the category "no v1siting" between father and child. According to both mother and father respondents, the modal expectancy of father-child visiting was about once a week. However, a mild directional difference in mother-father respondent replles was again noted. More fathers expected to have custody and to visit more than once a week while none sa1d they expected to contact their chlldren less than once a month in the future. About 10\% of mothers belleved their husbands would see the chlldren less than once a month in the future. Both mother (83\%) and father (78\%) respondents, however, seemed to belleve they were in agreement about visiting frequency in stating that the mother concurred in the amount of contact they planned. Nearly three-quarters of parent respondents expected these visits to take place mainly on weekends. A very similar pattern of response was given by mothers and fathers about the arrangements for these visits; there should be a special day such as Saturday or the visit 
should be "any convenient time as long as there is a telephone call first." Few respondents belleved it was necessary to pin down exact hours or, on the other hand, to be so permissive as to allow "drop ins" without warning.

b. Meaning of Visiting: The significance of the father's visits with his children was considered to be "very important" by less than half of the mother respondents but by more than $80 \%$ of the fathers. The majority of both parents' responses communicated the bellef that the most important purpose of these visits was to make the child feel secure and loved. Nelther was there marked disparity in other categorles deplcting the meaning of visiting, including the small percentages of parents giving much weight to "fathers' rights." Furthermore, the modal response of both mothers (40\%) and fathers (30\%) was that the father should be able to visit his child even if he never makes support payments. This may be a dimension with polarized attitudes since the next most common response category related fathers' rights to "regular" support payments rather than intermedlate choices such as "falrly regular," "some," or "seldom."

c. The Chlld's Role in Visiting: In considering the children's role and reaction to visiting, there was much in common in the preferences of the mother and father respondents with the exception of the age at which the child should help make visiting decisions. Although the modal response 
of all parents was age "13 and older," about half of the fathers belleved a child should help make such decisions by age 10 while only a quarter of the mothers agreed. The same trend may be seen in that more mother than father respondents belleved a child "should not help make main decisions." A common response for all parents was that the child loved the father "the same" since separation and that the child was neither "easier nor harder to handle" after a visit. While parents agreed that the child loved the father no less since separation, $29 \%$ of the mothers marked that the children "don't seem to think about" the father. By contrast this was a low frequency response category selected by father respondents.

d. V1siting Problems: It was only the exceptional parent (8\%) who expected "many" or "very many" problems in the visiting of the children. The modal response for both fathers and mothers was "very few" with the fathers expressing this optimistic view even more frequently. In the same vein, an overwhelming percentage of parents expressed the desire for the court to play no role in working out visitIng agreements or simply to order the customary "reasonable" visiting privileges. Despite their small numbers, two or three times as many fathers sald that the court should provide counselors to help work out visiting arrangements; 
twice as many fathers wanted the court to play an active role in spelling out details of visiting and seeing to it that the parents lived up to them.

The types of visiting problems that were expected by the respondents were assessed under headings of arrangements, the visit itself, and attitudes about visiting, $1 . e .$, special concerns such as drinking. Between a third and a half of the respondents reported they expected no problems In any of the dimensions examined. Fathers marked the "none" category more than mother respondents under each of the headings but this was especially true of the "attitude" heading. In that classification of problems, almost half the mothers expressed concern about fathers "questioning" children during visits. They also checked drinking, drivIng, and "other women" as sensitive points a little more frequently. More than a third of the father respondents indicated that there might be a problem in keeping the visits from becoming "just routine."

B. Rel1ab111ty of Questionna1re Items

1) Source of Varlance: A discrepancy in the response given on the malled questionnaire and on the same item during the interview might derive from several sources: a) ambiguity of the question and response categories; b) indec1sion or flux in the subject; c) appropriate changes in the 
subject's perceptions reflecting situational changes during the elapsed time between the two responses; d) situational response set in completing a malled questionnalre versus a face-to-face encounter; s) interviewer error or bias. The research team focused primarliy on the error varlance stemming from the questionnaire per se in order to work toward a revised Minor Child Questionnalre. Therefore, an attempt was made to take "realistic" changes into account in scoring agreement or non-agreement between malled and interview behavior. An obvious example is that the length of time the parents were separated should average about a month more at the time of the interview.

2) Scoring Agreement Criteria: Stringent criteria were used in scoring agreement between malled and interview responses so that blas would be in the direction of a rigid test of 1 tems. On almost all 1tems, the 1dentical response category had to be chosen in the two situations although in many cases the change might be minor. Th1s procedure was probably inappropriate for five-point scale items; however, Appendix $\mathrm{C}$ also includes the product-moment $r$ 's for these five 1tems. In all instances where an 1tem was omitted on elther the malled questionnaire or the personally admin1stered one, "non-agreement" was recorded. Also where an individual insisted on marking more than one response category in either measurement situation, this was considered 
"non-agreement." On a few questions, a definite degree of leeway was established in determining concordance. These were question \#4 (age), \#14 (length of marriage), and \#15 (age at marriage) where a difference of one year or less was scored as agreement. On question \#13 (Income), a discrepancy of $\$ 1000$ was tolerated. On question \#19 (length of time elapsed since divorce was first discussed), three months deviation was permitted for perlods of a year or less; six months for perlods of more than a year. In a number of Instances, the subject's non-verbal and Indirect verbal behavior during the interview was at odds with his category selection in terms of interviewer judgement; nevertheless, the interviewee's formal decision was used in the data analysis.

3) Percentage of Agreement: A determination of agreement or non-agreement was made for 46 1tems. The average percentage of agreement was $80 \%$ with a range of $40 \%$ to $100 \%$. If the $80 \%$ agreement cut-off 18 arbitrarily established as the lower limit for "good agreement," 25 of the analyzed questionnaire items met the criterion while 21 must be considered "falr" or "poor." Table 4 shows the breakdown of the "good," "fa1r," and "poor" 1tems when they are classified as calling for "factual information" versus "feeling or opinion." Most of the "factual" Items met the $80 \%$ agree- 
ment criterion and most of the "feeling or opinion" 1 tems met the standard of "fa1r" degree of agreement.

TABLE 4

PERCENTAGE OF AGREEMENT FOR FACTUAL VS. FEELING OR OPINION ITEMS

\begin{tabular}{lccccr}
\hline & \multicolumn{2}{c}{ Good } & Fa1r & Poor & \\
& 80\% to 100\% & 60\% to $79 \%$ & 40\% to 59\% & Total \\
\hline $\begin{array}{l}\text { Factual Items } \\
\begin{array}{l}\text { Feeling-0pinion } \\
\text { Items }\end{array}\end{array}$ & 18 & 1 & 1 & 20 \\
Total Items & 7 & 12 & 7 & 26 \\
\cline { 2 - 5 } & 25 & 13 & 8 & 46 \\
\hline
\end{tabular}

An analysis of the percentage of agreement between malled and interview responses was carried further to examine the content of the same 46 1tems. Table 5 shows the five broad content categories and the numbers of 1 tems which met the standard for "good," "falr" and "poor" agreement. Demographic 1tems, of course, produced the highest proportion of high-agreement 1tems. Two-thirds of the parent relationsh1p items also met the $80 \%$ agreement criterion. Some of the lowagreement 1 tems in the other content categorles were five- 
point rating scale items; nevertheless, these ratings all produced statistically significant r's with a .55 median value.

\section{TABLE 5}

PERCENTAGE OF AGREEMENT FOR ITEMS

IN CONTENT CATEGORIES

\begin{tabular}{|c|c|c|c|c|}
\hline & $\begin{array}{l}\text { Good } \\
80 \% \text { to } 100 \%\end{array}$ & $\frac{\text { Fa 1r }}{60 \% \text { to } 79 \%}$ & $\frac{\text { Poor }}{40 \% \text { to } 59 \%}$ & Tota1 \\
\hline Demograph1c & 7 & 1 & 0 & 8 \\
\hline $\begin{array}{l}\text { Parent } \\
\text { Relationship }\end{array}$ & 12 & 5 & 1 & 18 \\
\hline $\begin{array}{l}\text { V1sitation } \\
\text { Discussion }\end{array}$ & 1 & 1 & 2 & 4 \\
\hline $\begin{array}{l}\text { Custody } \\
\text { Practical } \\
\text { Expectancies }\end{array}$ & 2 & 0 & 1 & 3 \\
\hline $\begin{array}{l}\text { Present and } \\
\text { Expected } \\
\text { Visiting }\end{array}$ & 3 & 6 & 4 & 13 \\
\hline Total & 25 & 13 & 8 & 46 \\
\hline
\end{tabular}


C. Sample Representativeness

1) Minor Ch1ld Quest1onna1re (MCQ) Ma1l Sample: The demograph1c characteristics of the mall sample respondents were described above under II. The age, length of marriage, and number of children for the Minor Child Questionnalre respondents were compared w1th other stat1st1cs from Oregon as shown in Table 6. The Oregon Bureau of V1tal Statistics (BVS) report for 1968 pertalned to all divorces, but the 1969 Benton County f1gures (Griffith, et al, 1970) described only the divorces where minor chlldren were involved. There was a substantial similarity between the Minor Child Questionnalre mail respondent sample and the other two as inspection of the table shows. Including all divorces in oregon, the median age for husbands was 34.8 years and 31.8 years for wives in 1965, which again suggested that the Minor Child Questionnalre mall sample respondents did not markedly deviate on that dimension.

The median duration of marriages was 7.2 years nationally in 1965 but 5.9 in oregon including all marriages; modal polnts were one year and 10 to 12 years of marriage. For the same year nationally, the mean number of children per decree was 1.32 . These base rates from the Nat1onal Center for Health Statistics (1969) raise the question of the Minor Ch1ld Questionnalre sample being marrled longer and having 
more ch1ldren but 1 t must be recalled that the Minor Ch1ld Questionna1re respondent sample systemat1cally eliminated marriages without minor ch1ldren.

TABLE 6

AGE, YEARS MARRIED, AND NUMBER OF CHILDREN OF OREGON SAMPLES

\begin{tabular}{|c|c|c|c|c|c|c|}
\hline & $\begin{array}{r}\text { MCQ } \\
\text { Mother }\end{array}$ & $\frac{1971}{\text { Father }}$ & $\begin{array}{r}\text { BVS } \\
\text { Mother }\end{array}$ & $\frac{1968}{\text { Father }}$ & $\begin{array}{c}\text { Bentor } \\
\text { Mother }\end{array}$ & $\frac{1969}{\text { Father }}$ \\
\hline Age & 30.67 & 33.18 & 30.90 & 34.70 & 31.30 & 34.30 \\
\hline $\begin{array}{l}\text { Years } \\
\text { Married }\end{array}$ & 9.77 & 10.5 & & 59 & 10. & \\
\hline $\begin{array}{l}\text { Number } \\
\text { Ch1ldren }\end{array}$ & 2.09 & 2.09 & & 13 & & 05 \\
\hline
\end{tabular}

The educational level of the Minor Child Questionnalre respondents was typlcally high as observed in Table 7, especlally for fathers. Two samples which were drawn from the Fam1ly Services Department in 1964 (Karr) and In 1968 (Glaudin) are remarkably simllar educationally. Although these samples did include some childless couples, these Family Services Department clients were not unusually young or briefly married. It seems more likely that the $48 \%$ of Minor Child Questionnalre father respondents who had been 
exposed to some college experience represented a blased sample of divorcing parents; probably the $29 \%$ of Minor Ch1ld Questionnalre mother respondents who reported some college training also represented a sample bias. Relatively high income levels which were reported appear correlated with the blased educational level of respondents.

\section{TABLE 7}

EDUCATIONAL LEVEL OF QUESTIONNAIRE RESPONDENTS

\begin{tabular}{lrrrrrr}
\hline & \multicolumn{2}{c}{ MCQ 1971 } & \multicolumn{2}{c}{ FSD 1968 } & \multicolumn{2}{c}{ FSD 1964 } \\
\cline { 2 - 6 } & Mother & Father & Mother Father & Mother Father \\
\hline $\begin{array}{l}\text { High School } \\
\text { Graduate } \\
\text { or Less }\end{array}$ & $71 \%$ & $52 \%$ & $77 \%$ & $71 \%$ & $80 \%$ & $72 \%$ \\
$\begin{array}{l}\text { Some Col- } \\
\text { Iege or } \\
\text { More }\end{array}$ & $29 \%$ & $48 \%$ & $23 \%$ & $29 \%$ & $20 \%$ & $28 \%$ \\
\hline
\end{tabular}

2) Interview Sub-Sample: The attrition of subjects from the original pool through the Minor Ch1ld Questionnalre ma1l sample to the Minor Ch1ld Questionnalre Interview subsample provided further opportunity for sample blas as shown In Table 8. However, the factors of age, years of marrlage and number of chlldren reported for the interview sample were similar to the total Minor Chlld Questionnalre sample as shown in Table 8 below. 
TABLE 8

AGE, YEARS MARRIED AND NUMBER OF CHILDREN

OF MAIL SAMPLE AND INTERVIEW SUB-SAMPLE

\begin{tabular}{|c|c|c|c|c|}
\hline & $\frac{\text { Ma1l }}{\text { Mothers }}$ & $\frac{\text { Sample }}{\text { Fathers }}$ & $\begin{array}{l}\text { Interview } \\
\text { Mothers }\end{array}$ & $\begin{array}{l}\text { N Sample } \\
\text { Hathers }\end{array}$ \\
\hline Age & 30.67 & 33.18 & 31.65 & 32.00 \\
\hline $\begin{array}{l}\text { Years } \\
\text { Married }\end{array}$ & 9.77 & 10.51 & 10.24 & 10.90 \\
\hline $\begin{array}{l}\text { Number } \\
\text { Ch1ldren }\end{array}$ & 2.09 & 2.09 & 2.12 & 2.08 \\
\hline
\end{tabular}

On the other hand, if the mall sample respondents were educationally blased, the interview sub-sample was also blased by definition. Further, the attrition of subjects noted above in Table 8 produced the opportunity for aggravation of the non-representativeness of interviewees. Table 9 probably shows that this was the case in terms of education level. The mean number of years of education for mothers interviewed was 12.88 and 14.15 for fathers. 
TABLE 9

EDUCATIONAL LEVEL OF MAII SAMPLE

AND INTERVIEW SUB-SAMPLE

Ma11 Respondents Mothers Fathers
Interviewees Mothers Fathers

\begin{tabular}{lllll} 
High School Graduate & & & \\
or Less Education & $71 \%$ & $52 \%$ & $59 \%$ & $38 \%$ \\
$\begin{array}{l}\text { At Least Some } \\
\text { College }\end{array}$ & $29 \%$ & $48 \%$ & $41 \%$ & $62 \%$ \\
\hline
\end{tabular}




\section{DISCUSSION}

\section{A. Visiting}

The data provided by the sample of parents of minor chlidren palnted a benlgn picture in the first few weeks after a divorce petition is filed. Little difficulty was anticipated by the majority in maintaining a visiting relationship between the child and the non-custodial parent. Large numbers of respondents reported that they were able to cooperate in a friendly or businesslike manner rather than being embittered. V1siting was described as occurring on at least a weekly basis by most of the parents. Many sald they expected visiting to be weekly, mainly on a special day such as Saturday, but that visiting might take place at any convenient time as long as a telephone arrangement was made first. Although the parent respondents emphasized that visiting was important, especially for the sense of love and security in the child, they overwhelmingly expressed the desire to work out visiting arrangements for themselves with the court playing a minimal role. The traditional ordering of "reasonable" privileges appeared to meet the parents' needs.

There were several danger signals in the results which suggest that the parent respondents may be engaging in denial and pollyanna optimism doomed to disillusionment in 
many cases. First of all, the results showed that discusslon between parents about visiting was modest at best. Moreover, few parents reported that they had reached a clear agreement about visiting while one-third admitted they had reached no agreement. If Goode (1956) was correct in relatIng the amount of discussion to successful outcomes, many parents have disappolntments ahead. Father respondents especlally seemed to have high hopes for malntalning a very active, significant visiting relationship in contrast to the record of the "fading father" described in the I1terature. (Eckhardt, 1968.) Does th1s early-phase level of asplration correlate with dislliuslonment and subsequent withdrawal? St11l another point where the parents may be in for a shock is the role the children themselves will play in determinIng the visiting pattern. Parents in the present study expected children to contribute little to important visitIng declsions during middle childhood whereas Griffith, et al (1970), found that most children had an actlve volce by age elght or ten.

Not all the data were benign. For instance, it was common for the interviewers to note more signs of bitterness in the parents than they admitted. In some instances it was observed that this was aggravated by events in the adversary process, such as the allegations of the formal complaint, 
which occurred after the parent completed the malled questionnalre. In addition, there were hints that mothers and fathers viewed the visiting differently in a number of instances: the mothers belleved visiting to be less important; to be a threat in terms of the father questioning the child; and to pose hazards associated with wine, women and song. In keeping with Goode's finding (1956), some mothers confided in the interview that the importance of the father visiting would be sharply reduced if the mother remarried. Fathers, for their part, expressed a "responsible" attitude about the purpose of visiting and were more likely than mothers to state that fathers should earn their relationsh1p by support payments; however, several communlcated a change of heart during the interview after they had been hit with high support demands in the negotiation process. As for the visiting itself, fathers were a little concerned about routinizing the relationship with the child in the visiting arrangement.

\section{B. Questionnaire Reliablilty}

Since the results showed an $80 \%$ average agreement between malled questionnalre responses and subsequent interview responses, the general rellablilty of the questionnalre appears encouraging. Factual questions, as might be ex- 
pected, had higher rellabllity than 1tems calling for oplnion or feeling, so they should enjoy greater confidence in interpretation. A number of questionnaire 1tems dealing with visiting and visiting expectancies had lower reliab1lity so the data describing visiting must be more cautiously viewed. Th1s may be due in part to the fact that visiting patterns and expectancies sometimes undergo rapid changes so that some variance here could be attributed to the uncertainty of the respondent as much as the ambiguity of the questionnalre.

The comparison of malled responses with interview reactions provided the basis for revising the Minor child Questionnalre. Some additional questions w1ll be included In the revised Minor Chlld Questionnalre as the result of interview experience. These will elicit such information as the parents' expectations in regard to the amount of child support payments and the possibility of a custody fight. A few 1 tems w1ll be dropped completely. A number of 1tems should be greatly improved with minor changes in wording. Some of these questions require additional response categorles or instructions which permit multiple responses. A number of 1llustrative changes may be clted as follows:

1. The question on religious preference requires a "none" category.

2. Questions on Income must clarify separate or joint income. 
3. Questions referring to "previous separation" should specify "from present spouse."

4. The five-point rating scales need to include a "none" category such as "almost none" and "none," "very few" and "none."

Thus, pre-testing has made 1 t possible to vastly $1 \mathrm{~m}-$ prove the Minor Child Questionnaire. In a number of instances, however, changing the wording of an item may Increase the number of respondents marking it properly but may also provide an opportunity for evasion for others who might otherwise make a more definitive cholce. For example, asking "who wants the divorce more" should probably include a "same" response category; but, adding a "don't know" category to the questions on reconclilation may dilute the predictive value previously established. (Karr, 1964.) It must be kept in mind that something is both gained and lost in making the decisions involved in revising a questionna1re. Some decisions to revise an item should be based on emplrical prediction even though respondents are critical of $1 t .4$

\section{Sampling Representativeness}

Results appear to show that the present sampling procedure vastly improved upon previous methods (Griffith,

4 The Minnesota Multphasic Personal1ty Inventory 18 the most frequently implemented clinical instrument used with computerized predictive validity; yet, many of 1 ts questions seem odd or nalve. 
et al, 1970) so that respondents were not atyplcal in respect to age, length of marriage and number of ch1ldren. On the other hand, it appears that the present procedure selected respondents who were above average in education and probably in socloeconomic status. This sample bias introduces a significant limitation in interpreting the results from the study of both the content and the rellab1lity find1ngs.

In terms of content, one obvious expected difference between a well-educated sample of respondents and a less privileged group is the problem of money per se in the visiting arrangement. "Too little money" was not frequently Indicated as a barrier to visiting by the respondents in the present study where fathers were more commonly concerned with the psychological 1ssue of a "routine" parent-child relationship. The high level of education, especially of the interview sub-sample which formed the basis of the rellabll1ty estimate, probably blased the quallty of responses In a positive direction, 1.e., a less educated sample would probably have greater difflculty in comprehending the 1tems and responding rellably. Lezak (1968) found that respondents who completed high school were consistent in fllling out a Personal H1story Questionnalre, in terms of the criterion of a subsequent interview, but that those with less than a high school education made a number of errors. 
The significance of the sample blas may be mitigated by further analysis of the data. First of all, the mall sample respondents should be broken down into sub-samples by dichotomlzing at the high school graduation level. Then an 1tem-by-1tem comparison of the number omitted or answered in a glven direction may be carrled out. Secondly, the rellability of selected 1tems should be examined in terms of the consistency of the sub-sample of 27 husband-wife pairs who provided data. In addition to providing a new approach to the reliablilty estimate, this sub-sample may represent a sufficient range educationally to permit a correlation to be established between the number of years of schooling and the reliability index.

The procedure for eliciting the cooperation of a large, representative sample of divorcing parents with minor chlldren requires further improvement. Several points in the process need to be checked. A blas may have been introduced right from the start in terms of those divorce files which had addresses 11sted. Next, of course, the "other half" of the sample which did not respond desplte recelvIng the questionnaire represents an important source of bias. Although the return rate was satisfactory for a malled questionnalre, it was hoped that the official letter from the court would stimulate an unusually high level of cooperation. A better grasp of the subjects who did not 
respond (who are they?) and Increased understanding of the1r reasons is a necessary step; otherw1se, further innovation in the basic approach to divorcing parents is needed.

\section{A Dilemma of Preventive Mental Health}

Findings from the research team's respondents present a basic dilemma in terms of the best interests of the minor children involved. The data suggest that most parents may be engaging in a significant amount of denial of the pain of family dissolution in divorce. This phenomenon has been a common one in coping with serlous lilness and death. (Short and W1lson, 1969; Kubler-Ross, 1969.) In any event, it is clear that the parents expressed the view that the court should play a minimal role. Similarly very few were interested in professional help concerning the relationship of the minor child and his absentee parent which is compatIble with the San Marin County research. (Paget and Kern, 1960.) Apparently most parents believed that "everything was fine" and the parent-child relationship was a "private" matter. These parents still expect to be the sole determiners of the child's fate as long as they are within the bounds of the same laws that apply to other parents. This attitude may represent a serious obstacle to preventive mental health measures. Although the minor children experiencing family dissolution are in a high risk group, their parents may tend to deny this until there is a crisis. 
When the large numbers of divorces are considered, even the relatively low percentage of parents who expressed a desire for professional help represent a great demand for services and opportunity for preventive psychlatry. A full quarter of the father respondents stated this interest while $17 \%$ of mothers did so. The fathers might be guided away from the process of unrealistic expectations and subsequent disillusionment. Mothers probably need emotional support in that an entire half admitted that they had experienced the subjective feeling of being on the verge of a "nervous breakdown" at some point.

The evidence of the lack of discussion certainly points the way for one type of intervention. Less than half of the respondents reported that they had talked about visiting arrangements even with their lawyers! The apparent denial of the need to discuss the divorce w1th the children is another opportunity for mental health education. It is not unusual for parents to try to protect chlldren from tragedles only to increase the child's anxlety and sense of uncertainty. There is every reason to belleve that the children experiencing the loss of family ties may manifest an unrecognized depression under these clrcumstances. Some of the potential preventive measures should directly include the children. In considering the possibility of direct services to children it is interesting to consider the 
49

family constellations of the respondent sample and the distribution of children by age as shown in Tables 10 and 11 .

TABLE 10

SIZE OF FAMILY

$\mathrm{N}=88$

\begin{tabular}{lc}
\hline Number of Children & Percentage \\
\hline & \\
One Child Family & $29 \%$ \\
Two Children & $38 \%$ \\
Three Children & $20 \%$ \\
Four or More & $13 \%$ \\
\hline
\end{tabular}

TABLE 11

NUMBER OF CHILDREN BY AGE GROUP

$\mathrm{N}=181$

Age Group

Number

0 to $2+$

3 to $5+$

6 to $8+$

9 to $11+$

31

12 to $14+$

20

15 to $17 t$

20 
Just as "divorce counseling" may be useful to separating adult partners, "family divorce therapy" may be especlally beneficlal to the children. The possibility of initiating this type of service in the future should certainly be examined. 


\section{BIBLIOGRAPHY}

Buss, A. H. Psychopathology. New York: W1ley and Sons, 1966.

Coddington, R. Dean. "The Significance of Life Events as Et1ologic Factors in the Diseases of Children:

I. A Survey of Professional Workers." Unpubilshed paper, Ohio State University, College of Medicine, 1970 .

Despert, L. "Children of Divorce," Dolphin Books. New York: Doubleday, 1962.

Eckhardt, K. W. "Deviance, V1sibility and Legal Action: The Duty to Support," Soclal Problems, XV, 1968.

Glaudin, V., B. Griffith, G. Hack, E. Murphy, A. Wleman, A. Williams, and E. Van Lydegraf. Post-Divorce Visitation of Minor Children: An Exploratory Study. Portland: Fortland State University, 1970.

Glueck, S. and E. T. Glueck. Famlly Environment and Delinquency. Boston: Houghton Miffin Company, I962.

Goode, W. J. After Divorce. Glencoe, Illinols: Free Press, 1956.

Grollman, E. A. Explaining Divorce to Chllaren. Boston: Beacon Press 1969.

Hammersley, Richard. Personal communication. Portland, 1970.

Hansen, R. W. and S. J. Goldberg. "Casework in a Family Court," Social Casework, XLVIII, July, 1967.

Hunt, M. M. The World of the Formerly Married. Greenwich, Conn.: Fawcett Püblishing, Inc, 1967.

Kubler-Ross, El1zabeth, On Death and Dying. New York: The Macmillan Company, 1969, pp. 52-58.

Landis, J. T. "The Trauma of Children When Parents Divorce," Marriage and Family Living, XXII, February, 1960.

Leslie, G. R. The Family in Soclal Context. New York: oxford University press, 1967 . 
Locke, H. J. Predicting Adjustment in Marriage. New York: Henry Holt, 1951.

Multnomah County Juvenile Department Annual Report, Donald E. Long Home, Portland, Oregon, 1969.

Paget and Kern. Counseling Services to Parents and Children Involved in D1vorce Proceedings. San Bernardino, CaIIforn1a, 1960 .

Pollack, J. "When Parents Separate," Today's Health, XLV, June, 1967.

Rosenberg, M. Soclety and the Adolescent Self Image. Princeton, New Jersey: Princeton University Press, 1965.

Schwartz, A. C. "Reflections on Divorce and Remarriage," Soc1al Casework, XIIX, Apr11, 1958, pp. 213-217.

Short, M. J. and W. P. W1lson. "Roles of Den1al in Chronic Hemodialyses," in Archives of General Psychlatry, Vol. 20, Apr11, 1969, pp. 433-437.

Steinzor, B. When Parents Divorce: A New Approach to New Relations. New York: Pantheon Books, 1969.

Wadlington, W. "The Courts and Children's Rights," Ch1ldren, XVI, July, August, 1969, pp. 138-142. 
APPENDIXES 
APPENDIX A

1. Questionnalre and Results From The Malled Quest1onnalre For The Mother of a Minor Child

Today's Date

1) Name

2) Address

3) Telephone

4) Age $\bar{X}=30.67$ years $S=7.75$ years $\quad N=53$

5) I am: $\quad \mathrm{N}=54$

1. Wh1te.............. (52) $96 \%$

2. Negro................

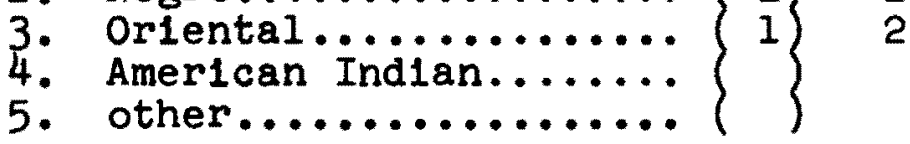

6) Mark the one that applies to you: $\quad N=53$

1. Protestant............ (33) $62 \%$

2. Catholic.............. 12$\}$

4. Jew1sh.................

7) How long have you lived at your current address? $N=51$

1. less than 6 months..... (13) $26 \%$

2. less than 1 year........ 5 ( 10

3. less than 5 years...... 18$\} 35$

4. more than 5 years...... (15) 29

8) Please Indicate the amount of schooling you have completed: $\quad \mathrm{N}=53$

1. $0-6$ years............ (0)

2. $7-9$ years........... (2) $4 \%$

3. $10-12$ years............ (5) 59

5. college -1 year........ 4 , $8 \quad \bar{X}=12.5$ years

6. college -2 years........ 6) 11

7. college -3 years...... 1 ( 2

$\left.\left.\begin{array}{l}\text { 8. college graduate................. } \\ \text { 9. post graduate...... }\end{array}\right\} \begin{array}{l}1 \\ 3\end{array}\right\} \begin{aligned} & 2 \\ & 6\end{aligned}$ 
9) Are you presently employed? $\quad \mathrm{N}=54$

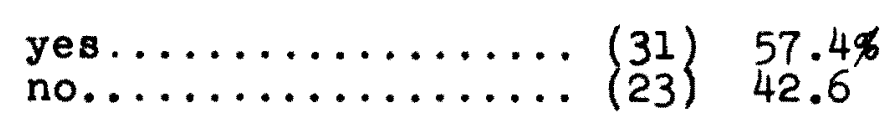

10) What kind of business or organization do (or did) you work for?

11) What is (or was) your job? What kinds of work do (or did) you do?

12) How long have you worked for your present or most recent employer? $\quad \mathrm{N}=42$

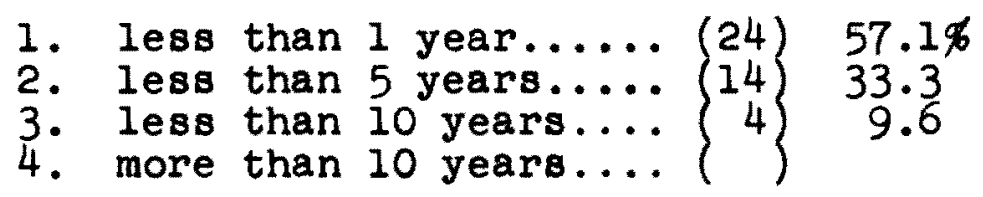

13) What is your income? $N=43$

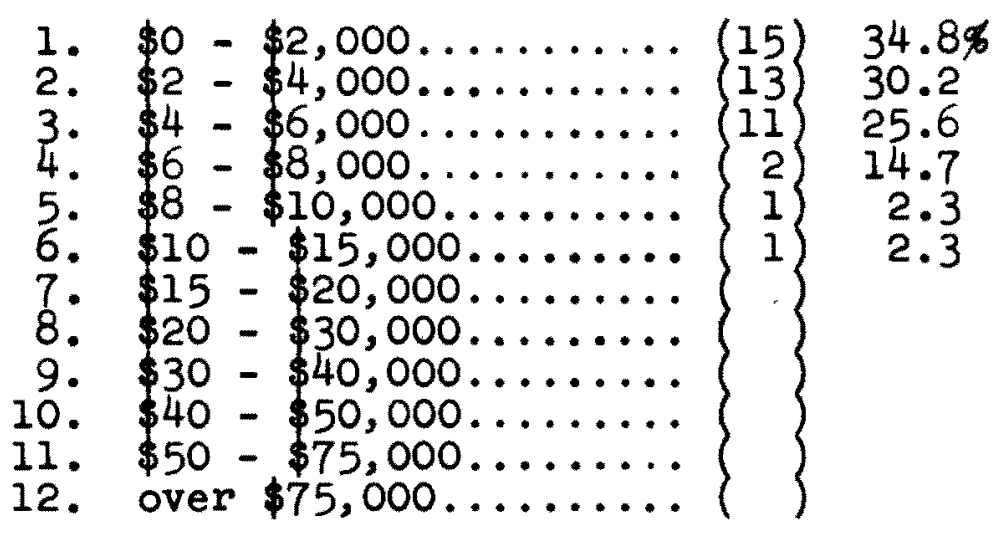

14) How long have you been marrled to your present husband? $\bar{X}=9.77$ years $S=6.39$ years $\quad N=53$

15) How old were you when you marrled your present husband? $\mathrm{X}=20.20$ years $\mathrm{S}=4.00$ years $\quad \mathrm{N}=50$

16) Have you been marrled before? $\quad \mathrm{N}=54$

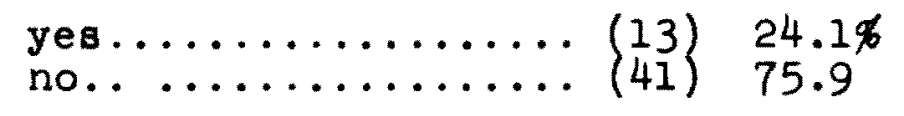


17) How long have you been separated from your present husband? $\quad \mathrm{N}=54$

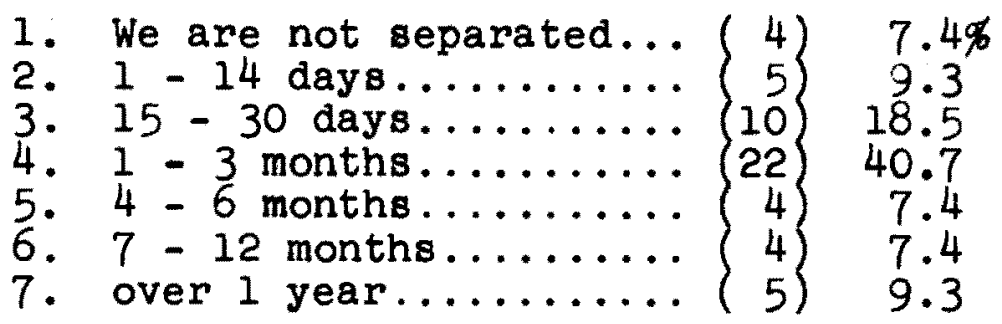

18) Have you been separated before? $\quad \mathrm{N}=53$

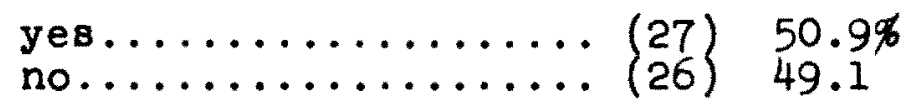

19) How long ago did you and your husband first talk about getting a divorce? $\bar{X}=22.08$ months $S=32.60$ months $N=45$

20) Who filed for this divorce? $\mathrm{N}=54$

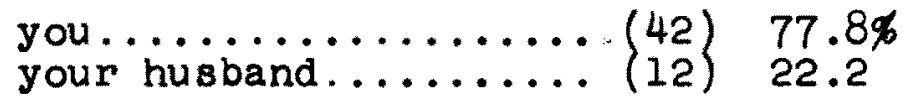

21) Who wants a divorce more? $\quad \mathrm{N}=47$

$\begin{array}{ll}\text { you } \ldots \ldots \ldots \ldots \ldots \ldots & 38 \\ \text { your husband........... } & 80.8 \% \\ 9 & 19.2\end{array}$

22) Do you want to reconcile? $\quad \mathrm{N}=53$

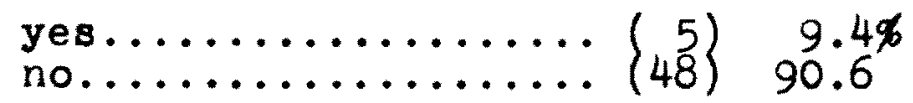

23) Do you belleve your husband wants to reconclle? $\quad N=47$ yes...................

24) If a divorce is granted, do you think you will be getting married to someone else during the coming year? $N=54$

1. yes............. (5) $9.3 \%$

2. no................... 42$\}$

3. not sure............. 7 (7) 13.0 
25) If a divorce is granted, do you think your husband will be getting married to someone else during the coming year? $\quad \mathrm{N}=54$

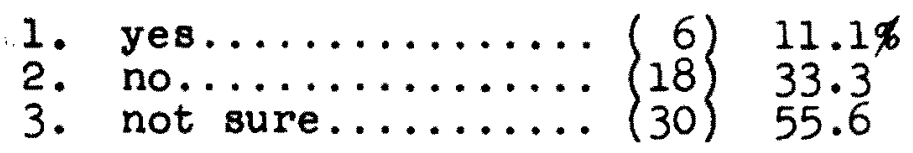

26) Place an " $X$ " by all the problems that apply to your husband. You may mark more than one. $\quad \mathrm{N}=57$

1. nervousness....... (22)

2. depression or

$$
\text { "blues" .......... (22) }
$$

3. bad temper......... (31)

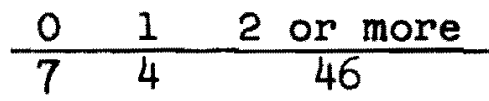

4. coldness or lack of showing affection. (34)

5. sex problems....... (22)

6. heavy drinking or alcoholism........ (23)

7. drug abuse or

8. poor work record...

10. none of these problems......... ( 7 )

27) Place an " $X$ " by all the problems that apply to you. You may mark more than one. $\quad N=56$

1. nervousness.

2. depression or

"blues".....

3. bad temper........ (15)

4. coldness or lack of showing affection.

5. sex problems....... (12)

6. heavy drinking or alcoholism......... (1)

7. drug abuse or

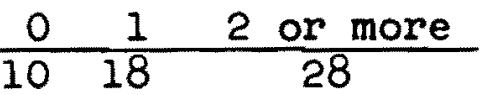

8. poor work record....

9. poor health....... (8)

10. none of these problems............. (10) 
28) Have you ever had a nervous breakdown? $\quad \mathrm{N}=54$

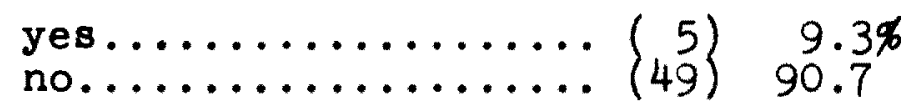

29) Have you ever felt you were golng to have a nervous breakdown? $\quad \mathrm{N}=52$

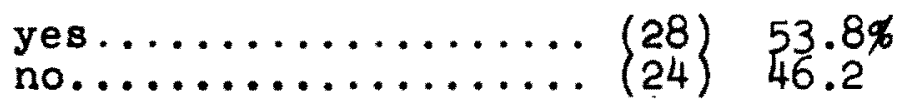

30) Has your husband ever had a nervous breakdown? $\quad \mathrm{N}=54$ yes.......................
no...

31) Have you ever wanted your husband to be punlshed? $N=51$

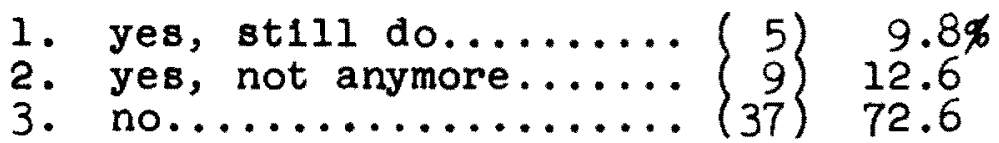

32) At the present time, do you feel bitter toward your husband? $\quad \mathrm{N}=54$
1. very much bitterness...
2. much bitterness........ 3) 5.6
3. some bitterness......... 11 20.4
4. a little bitternes8.... 9 16.7
5. no bitterness......... (28) 51.9

33) At the present time, how would you describe your relationship with your husband? $\quad \mathrm{N}=47$
1. friendly.
busines $-11 k \ldots \ldots \ldots$ (21) $44.7 \%$
3. angry and silent....... $13,27.7$
4. angry and fighting..... 2) 4.2
5. other............... (9) 19.2 describe

34) How much discussion have you had with your husband about visiting your children? $\quad \mathrm{N}=52$
1. almost none........... (12) $23.1 \%$
2. 11ttle.............. 10 (10) 19.2
3. some............. 12 (2) 23.1
4. much................. 8 8 15.4
5. very much.............. (10) 19.2 
35) How much discussion have you had with one or more of the children about visiting? $\quad \mathrm{N}=48$

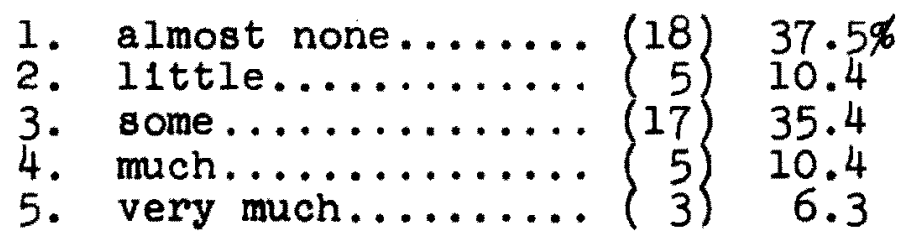

36) Who has given you advice or counseling about the visiting of the children? You may mark more than one. $\mathrm{N}=53$

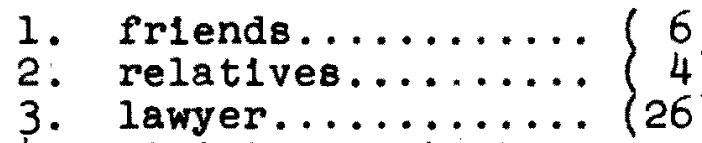

4. minister, priest

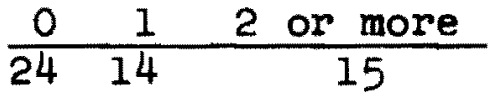
or rabb1.

5. medical doctor..... 3$\}$

6. social worker...... 2 ?

7. psychlatrist.......

9. Family Services Department of the Multnomah County no one...............

37) Would you like to have professlonal advice or counseling about the visiting of the children? $\quad \mathrm{N}=52$

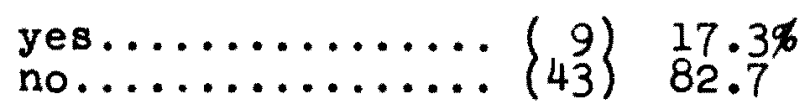

38) Have you and your husband reached an agreement about visiting your children? $\quad \mathrm{N}=51$

1. very clear agreement.(13) $25.5 \%$

2. general agreement... 15 (15) 29.4

3. some agreement...... 6 11.8

4. 11ttle agreement.... ( 0

5. no agreement....... (17) 33.3 
39) Are any of your minor children (18 and under) 11ving with you now? $\quad \mathrm{N}=53$
1. no....................... (3) $5.7 \%$
2. yes, I'm living with my husband and children................. (6) 11.3
3. yes, at least one of my children 18 living with me............ (44) 83.0

40) At present, when the children are not in school, does anyone help take care of them in addition to the parents? $\quad \mathrm{N}=48$

1. baby sitter comes in once in a
2. baby sitter comes in falriy regularly................... (5) 10.4
3. nelghborhood baby sitter's home falrly regularly.
4. nursery school or pre-school
(8) 16.7
falrly regularly
5. day care center fairly
(1) 2.1
regularly
6. relatives.
7. no, children look after them-
8. no, parent is aiways at home....... (12) 25.0

41) If a divorce 18 granted, where do you expect the ch11dren to live? $\quad \mathrm{N}=54$
1. With my husband $\ldots \ldots \ldots \ldots \ldots \ldots \ldots \ldots\left(\begin{array}{r}2) \\ 2 \text { w1th me }\end{array} 3.7 \%\right.$
3. at least one with my husband and

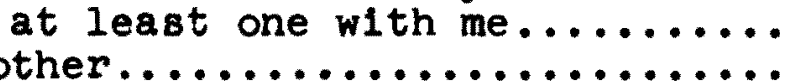
4. other...

42) If a divorce 18 granted, do you expect your husband to work for pay outside the home? $\quad \mathrm{N}=42$

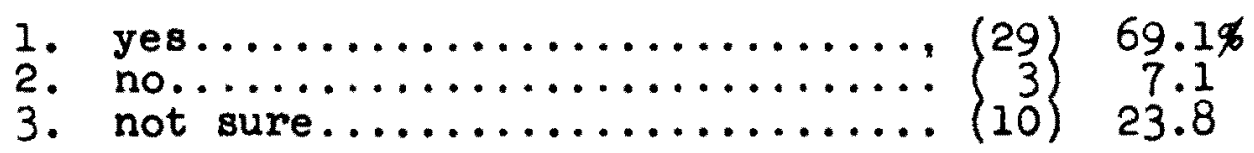


43) How frequently has your husband visited the chlldren during your separation? $\quad \mathrm{N}=49$

1. not separated................

2. separated but all chlldren are

(3) $6.1 \%$

with $h 1 m \ldots \ldots \ldots \ldots \ldots \ldots \ldots$ (2) 4.1

3. more than once a week......... (11) 22.5

4. about once a week............ (10) 20.4

5. about tw1ce a month........... (6) 12.3

6. about once a month ........... 4 , 8.2

7. less than once a month......... 2) 4.1

8. every few months............ (3) 6.1

9. on special occasions and

vacations only .............. (0)

10. less than once a year...........

11. none................ 8) 16.2

44) During your separation, what has been the effect of your husband's visiting the chlldren? $\quad \mathrm{N}=46$

1. no separation............... (3) $6.5 \%$

2. no visiting............... 5 5 , 10.9

3. all the children ilve with him.. (2) 4.4

4. children are all too young to show any effect............. (7) 15.2

5. makes them easler for me to handle.................... (0)

6. makes them harder for me to handle...................... (11) 23.9

7. same, not easler or harder for me to handle................. (18) 39.1

45) During your separation, what are the chlldren's feelings toward your husband? $\quad \mathrm{N}=48$

1. no separation............... 3) $6.3 \%$

2. they seem to love him more..... 1 ( 2.1

3. they seem to love him the same...

5. they don't seem to think about

him........................ (14) 29.1 
46) How frequently do you expect your husband to visit the children in the future? $\quad \mathrm{N}=41$

1. expect them all to live with h1m..

2. more than once a week............

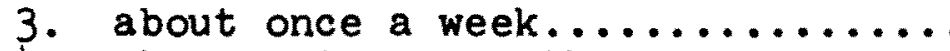

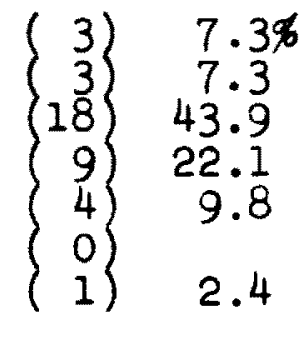

4. about twice a month.............

5. about once a month..............

6. less than once a month........... 7. every few months........................

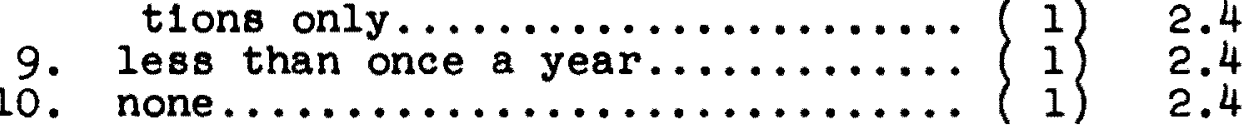

47) Do you want your husband to visit the ch1ldren? $N=48$

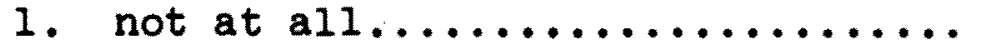
2. I want him to visit less fre-
(2) $4.2 \%$
quently than he expects to visit. (2) 4.2
3. I want him to v1sit more fre- quently than he expects to v181t. (4) 8.3
4. I want him to visit about the same
as he expects to visit.......... (40) 83.3

48) When do you expect your husband to visit the children in the future? $\quad \mathrm{N}=44$

1. malnly on weekends............ (30) $68.1 \%$

2. malnly during the week........... (4) 9.1

3. malnly at special times like

birthdays and holldays......... (2) 4.6

4. mainly his vacation or the children's summer vacation........... (3) 6.8

5. I do not expect $\mathrm{hIm}$ to visit...... (3) 6.8

6. I expect the children to be ilving w1th him.................. (2) 4.6 
49) What arrangements should be made for your husband's visits? $\quad \mathrm{N}=42$

1. arrange special hours such as 12 noon to $5: 00$ p.m................ (1) 2.4\%

2. arrange special days such as on Saturdays................. (8) 19.2

3. arrange spectal days such as holldays and vacations......... (0)

4. arrange any time that 1 s convenient as long as there is a telephone call first.......... (27) 64.3

5 . by just dropping in on the chil-

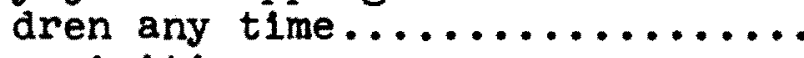

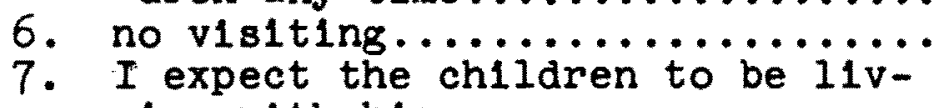
ing with him.................. (2) 4.7

50) At what age do you think a child should help make the main decisions about visiting with your husband? $\mathrm{N}=52$

1. should not help make main

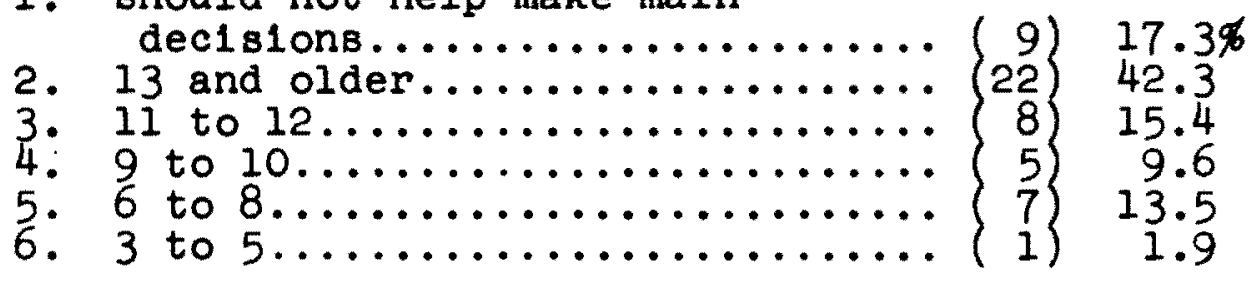

51) How 1mportant do you feel 1t 1s for your husband to visit the children in the future? $\quad \mathrm{N}=52$

1. not important at all.......... (2) $3.8 \%$

2. unimportant.................. 1) 1.9

3. not sure................. $13,25.0$

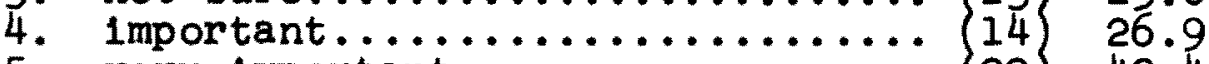

5. very 1mportant............... (22) 42.4

52) What do you belleve is the most important purpose of your husband visiting the children? $\quad \mathrm{N}=40$

1. no real purpose or value.........(0)

2. Just to maintain contact between father and ch1ld........ (5) $12.5 \%$

3. help the child feel secure or

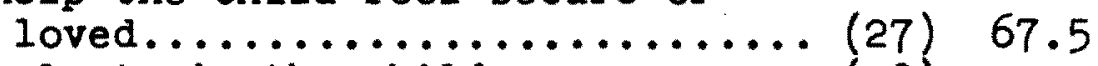

4. help train the child............ (0)

5. every father has a right to v1s1t h1s ch1ld.............. (8) 20.0 
53) What is the connection between your husband paying child support and visiting the children? $\quad \mathrm{N}=45$

1. He should have the right to visit as long as his payments are regular.... (14) $31.1 \%$

2. He should have the right to vist if his payments are usually regular.... (7) 15.5

3. He should have the right to visit as long as he makes some payments....... (2) 4.4

4. He should have the right to visit even if he seldom makes payments.... (3) 6.6

5. He should have the right to visit

even if he never makes a payment.... (18) 40.0

6. I expect all the minor children to live with him..................... (1) 2.3

54) What part should the court play in working out a visiting agreement? $\quad \mathrm{N}=45$

1. none. leges and leave detalis to parents.. (26) 57.8

3. provide counselors to help parents work out details of visiting agreements......................... (2) 4.4

4. provide counselors for parents if problems arise in visiting agreements $\ldots \ldots \ldots \ldots \ldots \ldots \ldots \ldots \ldots$ (1) 2.2

5. spell out the detalis of visiting agreement after checking with the parents or their lawyers............ (4) 8.9

6. spell out the detalls of visiting agreement after checking with the parents and their lawyers and see to 1 that the parents live up to the agreement................ (4) 8.9

55) Do you expect any problems with your husband visiting the children? $\mathrm{N}=52$

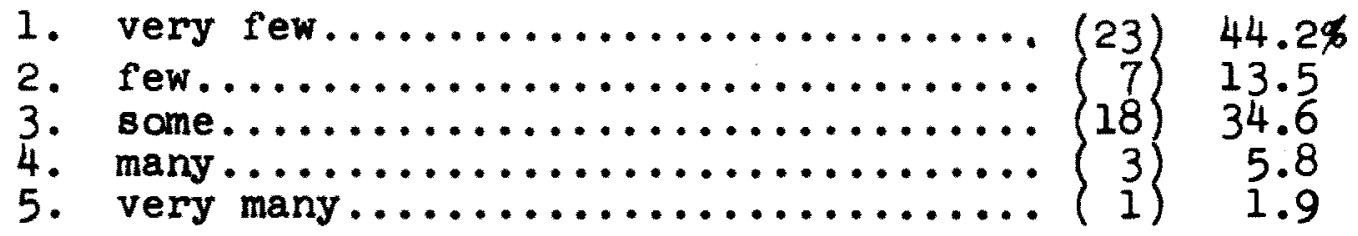


56) What problems do you expect your husband to have in arranging visits with the children? You may mark more than one. $\quad \mathrm{N}=52$

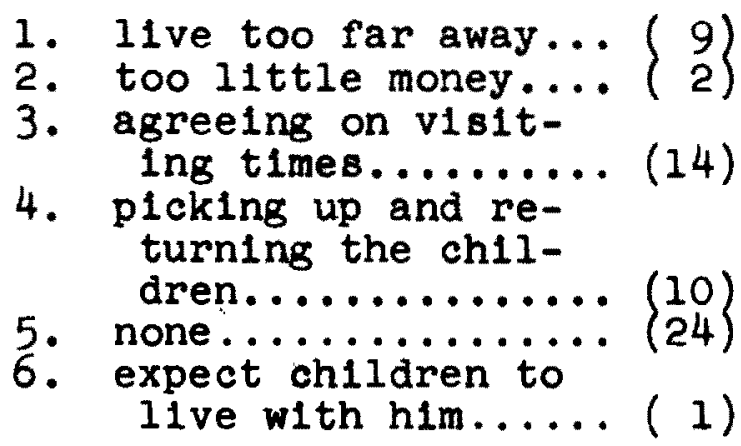

57) What problems do you expect your husband to have while visiting the chlldren? You may mark more than one. $\mathrm{N}=51$

1. where the visit takes place........ (14)

2. uncomfortable belng with the children $\frac{0}{24}-\frac{1}{21} \frac{2 \text { or more }}{8}$ in a visiting situation.......... (11)

3. things for the ch1ldren to do..... (12)

4. keeping the visits from becoming "just routine".....

5. none............. ( $\left.\frac{12}{8}\right)$

58) What problems do you expect to have with your husband's attitude about visiting the children? You may mark more than one. $\quad \mathrm{N}=52$

1. about his drinking.. (11)

2. about his friendship with other women............. (12)

$\frac{0}{18} 20 \quad \frac{1}{13}$

3. about his automo-

$\frac{0}{18} \frac{1}{16}-\frac{2}{18}$ or more

4. about religion....... 4$\}$

5. about questioning the children during a visit....... (23)

6. none............ (18) 
59) List all your chlldren from the present marriage starting with the oldest: $\quad \mathrm{N}=53$

First Name

1.

2.

3.

4.

5.

6.

7 .

8.

Number of children...... $\bar{X}=2.09$
Age Relationship

( ) son ( ) daughter

() son ( ) daughter

() son ( ) daughter

() son ( ) daughter

( ) son ( ) daughter

() son ( ) daughter

() son ( ) daughter

( ) son ( ) daughter 
APPENDIX A

2. Questionna1re and Results From The Ma1led Questionna1re For the Father of a Minor Child

1) Name

2) Address

3) Telephone

4) Age $\bar{x}=33.19$ years $\quad \mathrm{S}=8.75$ years $\quad \mathrm{N}=54$

5) I am: $\mathrm{N}=54$

1. Wh1te............. (51) $96.3 \%$

2. Negro................ 1 , 1.9

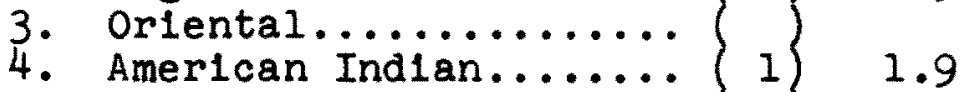

5. other................ (1) 1.9

6) Mark the one that applies to you: $\quad N=54$

1. Protestant............ (30) $55.5 \%$

2. Cathol1c............. 10 18.5

4. other..................

7) How long have you lived at your current address? $\quad N=54$

1. less than 6 months..... (25) $46.3 \%$

2. less than 1 year.......

3. less than 5 years....... 15 , 27.7

4. more than 5 years...... (5) 9.4

8) Please indicate the amount of schooling you have completed: $\quad \mathrm{N}=54$

1. $0-6$ years............

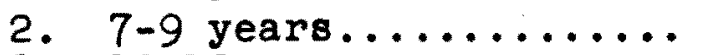

3. 10-12 years.

4. high school graduate...

5. college - 1 year.......

6. college -2 years.......

7. college -3 years......

8. college graduate.......

9. post graduate..........

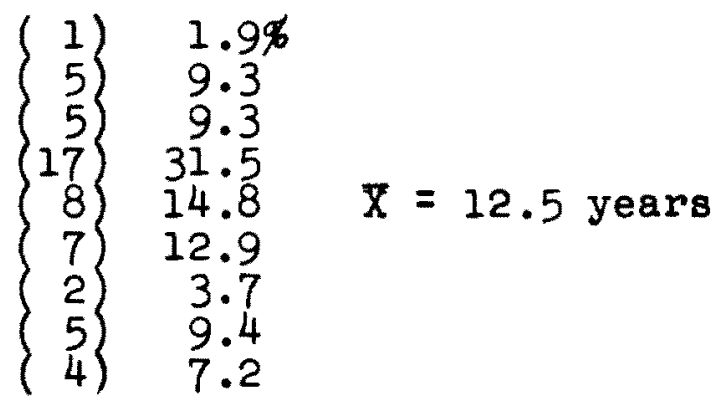


9) Are you presently employed? N 53

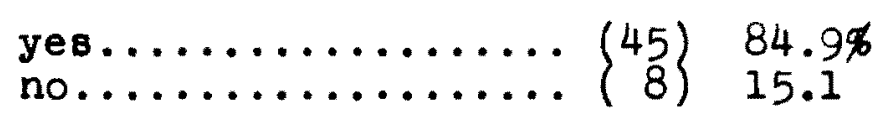

10) What kind of business or organization do (or did) you work for?

11) What is (or was) your job? What kinds of work do (or did) you do?

12) How long have you worked for your present or most recent employer? $\quad \mathrm{N}=52$

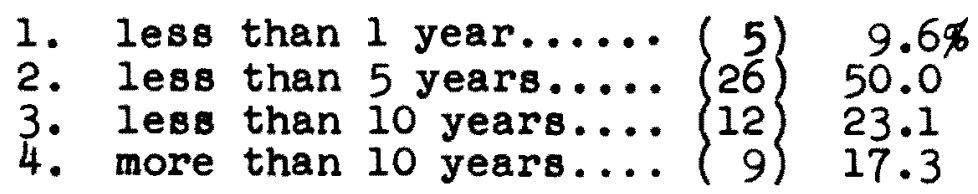

13) What is your income? $N=49$

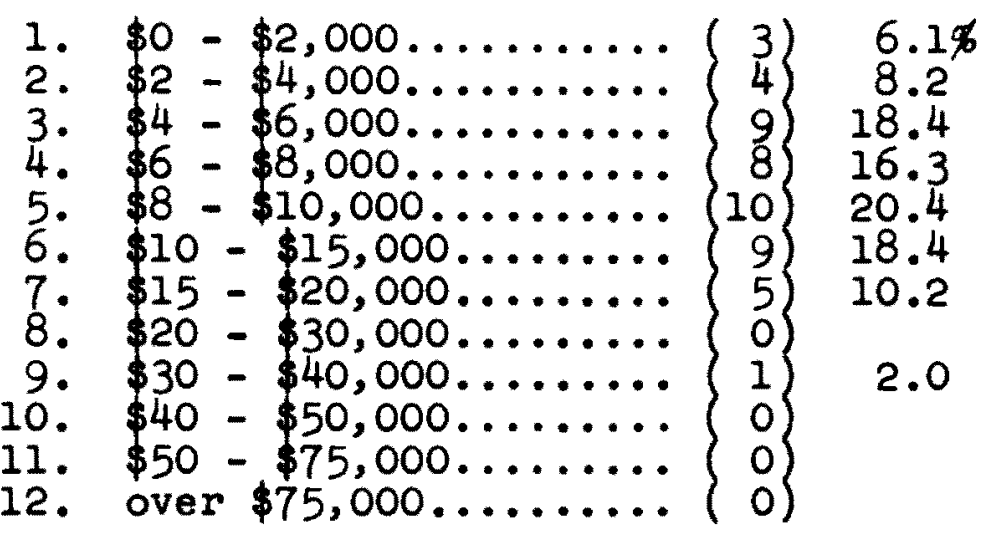

14) How long have you been married to your present wife? $\overline{\mathrm{X}}=10.51$ years $S=7.15$ years

15) How old were you when you marrled your present wife? $x=22.49$ years $S=4.01$ years

16) Have you been married before?

$$
\text { yos.................... }
$$


17) How long have you been separated from your present wife? $\quad \mathrm{N}=53$

1. We are not separated... (10) $18.9 \%$

2. 1 - 14 days........... 3 3 5.7

3. $15-30$ days........... 73 13.2

4. 1 - 3 months........... 14$\} 26.4$

5. 4 - 6 months.......... 10 18.9

6. 7 - 12 months.......... 6$\} 11.3$

7. over 1 year............ 3) 5.6

18) Have you been separated before? $\quad N=54$

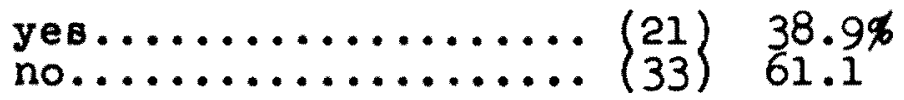

19) How long ago did you and your wife f1rst talk about getting a divorce? $\bar{X}=17.24$ months $S=32.6$ months $\mathrm{N}=45$

20) Who flled for this divorce? $\quad N=54$

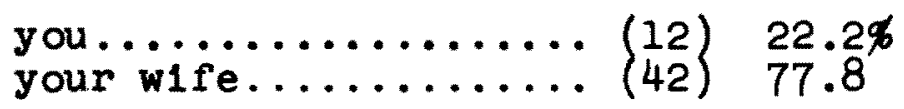

21) Who wants a divorce more? $\quad N=47$

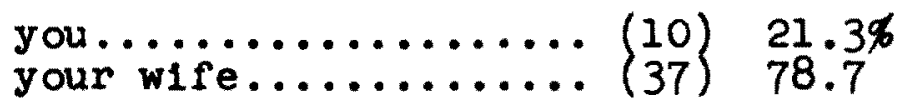

22) Do you want to reconcile? $N=48$

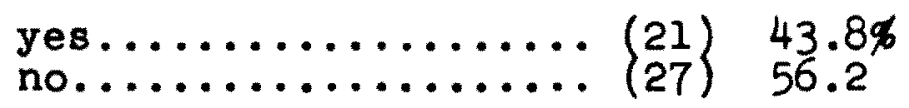

23) Do you belleve your wife wants to reconclle $N=49$

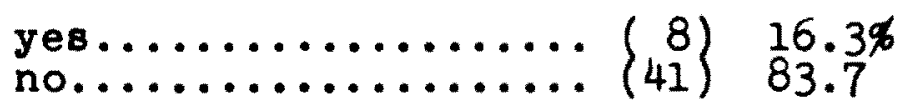

24) If a divorce is granted, do you think you w1ll be getting married to someone else during the coming year? $N=54$

1. yes............... (1) $2.0 \%$

2. no................. 43$\} 79.6$

3. not sure.............. (10) 18.4 
25) If a divorce $1 \mathrm{~s}$ granted, do you think your wife will be getting married to someone else during the coming year? $\quad \mathrm{N}=53$

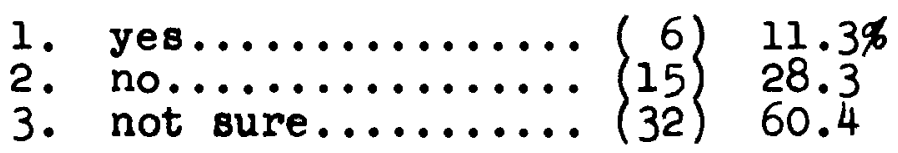

26) Place an " $\mathrm{X}$ " by all the problems that apply to your wife. You may mark more than one. $\quad \mathrm{N}=57$

1. nervousness........ (33)

2. depression or "blues".......... 36$)$

3. bad temper.......... (28) \begin{tabular}{ccc}
0 & 1 & 2 or more \\
\hline 3 & 8 & 46
\end{tabular}

4. coldness or lack of showing affection. (32)

5. sex problems....... (24)

6. heavy drinking or alcohollsm........ (4)

7. drug abuse or addiction.........

8. poor work record... 6

9. poor health........ 9)

10. none of these problems.......... (3)

27) Place an " $X$ " by all the problems that apply to you. You may mark more than one. $\quad \mathrm{N}=55$

1. nervousness........ (28)

2. depression or "blues"........... (23)

3. bad temper......... (19) \begin{tabular}{ccc}
0 & 1 & 2 or more \\
\hline 6 & 16 & 33
\end{tabular}

4. coldness or lack of showing affection. $\left(\begin{array}{r}15 \\ 7\end{array}\right)$

5. sex problems....... $(7)$

6. heavy drinking or alcohollsm........ (6)

7. drug abuse or addiction......... (0)

8. poor work record... 3$\}$

9. poor health........ (3)

10. none of these problems.......... (6) 
28) Have you ever had a nervous breakdown? $\quad \mathrm{N}=52$

$$
\text { yes................. }
$$

29) Have you ever felt you were golng to have a nervous breakdown? $\mathrm{N}=53$

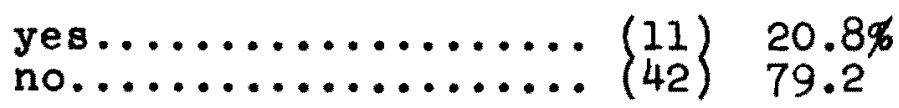

30) Has your w1fe ever had a nervous breakdown? $\mathrm{N}=50$ yes.................... (45) $10.0 \%$

31) Have you ever wanted your wife to be punished? $N=52$ 1. yes, st1ll do......... 5 (5) $9.6 \%$

2. yes, not anymore....... 7$\} \begin{array}{r}73.5 \\ 76\end{array}$

3. no................... (40) 76.9

32) At the present t1me, do you feel b1tter toward your w1fe? $\quad \mathrm{N}=53$

1. very much bitterness... $\left(\frac{1}{3}\right) \quad 1.9 \%$

2. much b1tterness....... 3$\} \quad 5.7$

3. some b1tterness........ 6 6) 11.3

4. a little bitterness.... (17) 32.1

5. no b1tterness........... (26) 49.0

33) At the present time, how would you describe your relationship with your wife? $\quad N=48$

1. frlendly............ (15) 31.3\%

2. business-ilke......... 21) 43.7

3. angry and sllent....... 10 20.8

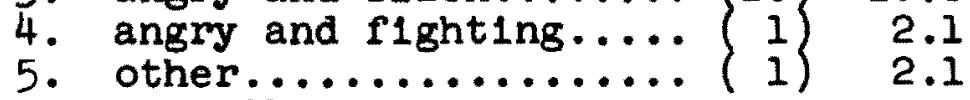
describe

34) How much discussion have you had with your wife about visiting your children? $\quad N=53$

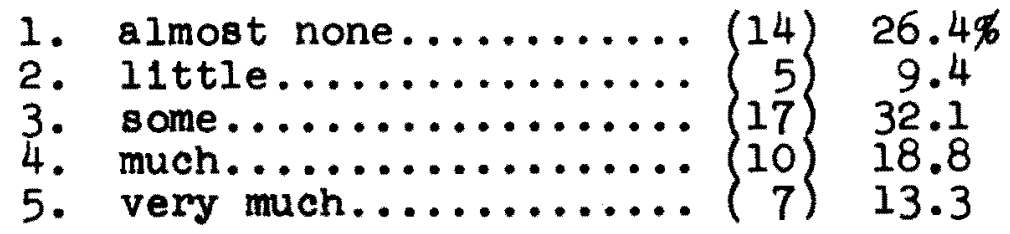


35) How much discussion have you had with one or more of the children about visiting? $\quad N=49$

1. almost none......... (25) $51.0 \%$

2. I1ttle.............. 5 , 10.2

3. some................ 9 9 18.4

4. much................ 6 (2.2

5. very much............ 4 , 8.2

36) Who has given you advice or counseling about the visiting of the children? You may mark more than one. $\mathrm{N}=57$

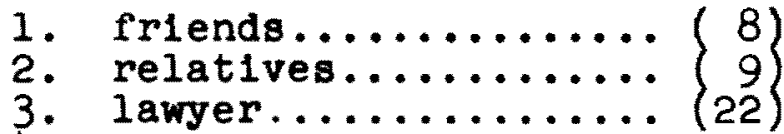

4. minister, priest or

$$
\text { rabb1.............. 2) }
$$

5. medical doctor........

6. soclal worker........., o

7. psychlatrist......... 0

8. psychologist......... (2)

9. Family Services

Department of the

Muitnomah County

10. No one..............

37) Would you like to have professional advice or counseling about the visiting of the children? $\mathrm{N}=50$

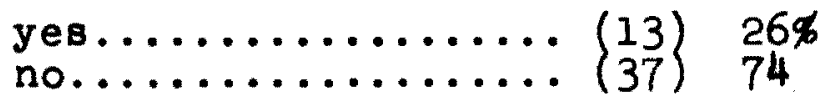

38) Have you and your wife reached an agreement about visiting your children? $\quad \mathrm{N}=54$

1. very clear agreement... (14) 25.6\%

2. general agreement..... 13 (3) 24.1

3. some agreement........ 5 ( 9.3

4. 11ttle agreement...... 2) 3.7

5. no agreement......... (20) 37.3 
39) Are any of your minor children (18 and under) living with you now? $\mathrm{N}=53$

1. no.................... (39) $73.6 \%$

2. yes, I'm living with my wife and chlldren................... (9) 17.0

3. yes, at least one of my children is living with me............. (5) 9.4

40) At present, when the children are not in school, does anyone help take care of them in addition to the parents? $\quad \mathrm{N}=34$

1. baby sitter comes in once in a

2. baby sitter comes in rärïy regularly ................. (3) 8.8

3. nelghborhood baby sitter's home fairly regularly............ (4) 11.8

4. nursery school or pre-school falrly regularly.............. (1) 2.9

5. day care center falrly

6. relatives..................... (10) 29.4

7. no, chlldren look after them-

8. no, parent is aiways at home..... ( $\left.\begin{array}{l}8 \\ 6\end{array}\right) \begin{aligned} & 23.5 \\ & 17.7\end{aligned}$

41) If a divorce is granted, where do you expect the children to live? $\quad N=54$

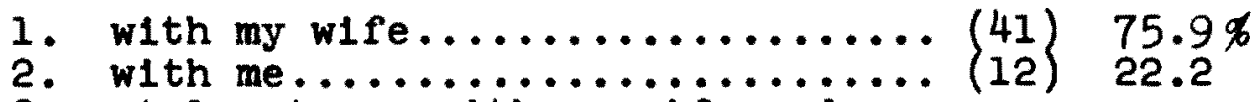

3. at least one with my wife and

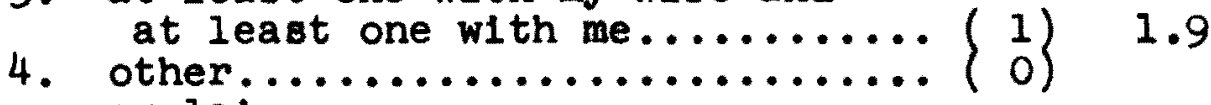
explain

42) If a divorce is granted, do you expect your wife to work for pay outside the home? $\quad \mathrm{N}=53$

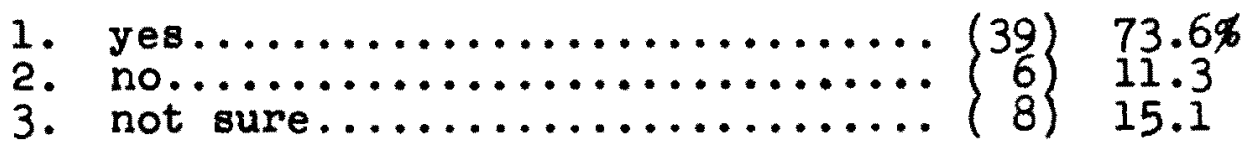


43) How frequently have you visited the children during your separation? $\quad \mathrm{N}=54$
1. not separated.......... (9) $16.6 \%$
2. separated but all the chlldren are w1th me... (4) 7.4
3. more than once a week... (12) 22.2
4. about once a week....... 17 (7) 31.5
5. about twice a month..... 5) 9.3
6. about once a month...... 4$\} 7.4$
7. less than once a month.. $\}$ o 0$\}$
9. on speclal occasions
and vacations only..... (0)
10. less than once a year... (1) 1.9
11. none................ (2) 3.7

44) During your separation, what has been the effect of your visiting the children? $\quad \mathrm{N}=51$
1. no separation.......... (9) $\begin{gathered}17.6 \% \\ 2 .\end{gathered}$
3. all the children live
with me.............. (4) 7.8
4. chlldren are all too young to show any effect................. (11) 21.6
5. makes them easier to handle for the mother.. (3) 5.9
6. makes them harder to handle for the mother.. ( 4) 7.8
7. same, not easler or harder to handle for the mother............. (20) 39.4

45) During your separation, what are the children's feelings toward you? $\quad \mathrm{N}=52$
1. no separation
2. they seem to love me
(10) $19.2 \%$ more.
3. they seem to love me

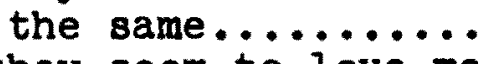
(15) 28.8
4. they seem to love me less....................
5. they don't seem to think about me............
(24) 46.2
(1) 1.9
( 2) 3.9 

46) How frequently do you expect to visit the children
in the future?

1. expect them all to live with me...

2. more than once a week...........

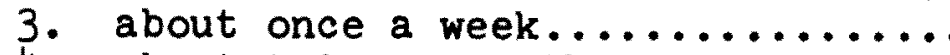

4. about twice a month................

5. about once a month................

6. less than once a month..............

7 - every few months.............. (0)

(11) $21.2 \%$

(10) 19.2

$20\} 38.5$

8. On speclal occasions or vaca-

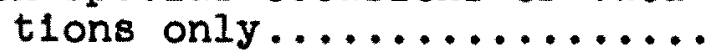

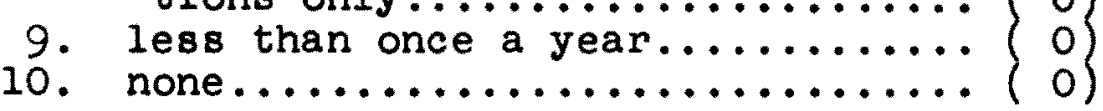

47) Do you think your wife wants you to visit the ch1ldren? $\mathrm{N}=46$

1. She does not want me to visit with them at all............... (2) $4.3 \%$

2. She wants me to visit less frequently than I expect to visit........................ (7) 15.2

3. She wants me to visit more frequently than $I$ expect to v1s1t.......................... (1) 2.2

4. She wants me to visit about the same as I expect to visit....... (36) 78.3

48) When do you expect to visit the children in the future? $\quad \mathrm{N}=49$

1. mainly on weekends $\ldots \ldots \ldots \ldots \ldots \ldots$ (35) $71.4 \%$

3. mainly at special times ilke

b1rthdays and holldays........... (1) 2.0

4. mainly my vacation or the children's summer vacation............. (1) 2.0

5. I do not expect to visit. . 3 iiving with me..................... (10) 20.4 
49) What arrangements should be made for your visits? $\mathrm{N}=47$

1. arrange speclal hours such as 12 noon to $5: 00$ p.m.............. (1) $2.1 \%$

2. arrange spectal days such as on Saturdays.................... (11) 23.4

3. arrange special days such as holldays and vacations......... (0)

4. arrange any time that is convenlent as long as there is a telephone call first.......... (24) 51.1 5 . by just dropping in on the children any time.................. 3) 6.4

6. no visiting.................. 1

7. expect the children to be Iiving with me............... (7) 14.9

50) At what age do you think a child should help make the main decisions about visiting with you? $\mathrm{N}=50$

1. should not help make main dec1-

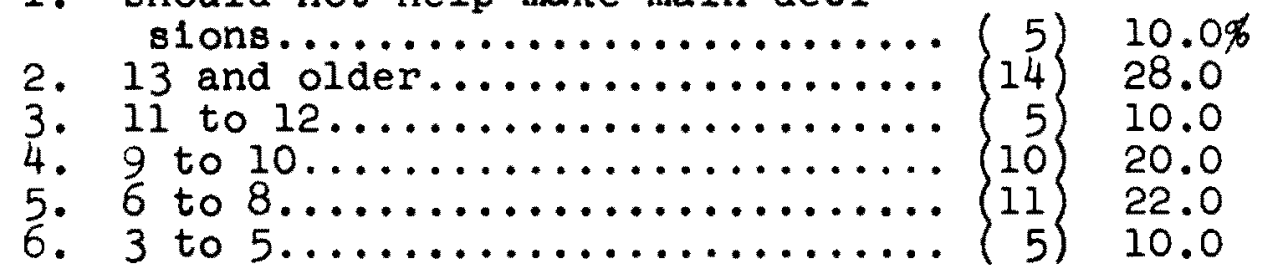

51) How 1mportant do you feel it is for you to visit the children in the future? $\quad N=53$

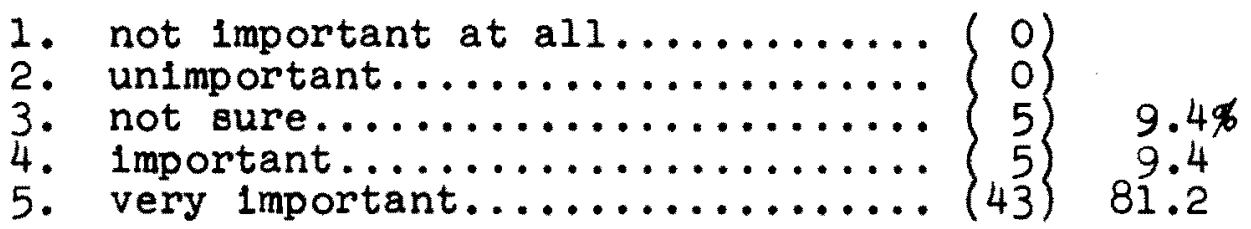

52) What do you belleve is the most important purpose of your visiting the children? $\quad \mathrm{N}=37$

1. no real purpose or value........ ( 0 )

2. Just to maintain contact between father and child....... (7) 18.9\%

3. help the child feel secure or loved...................... (23) 62.2

4. help train the child........... (2) 5.4

5. every father has a right to visit his child.............. (5) 13.5 
53) What is the connection between your paying child support and visiting the children? $\mathrm{N}=46$

1. I should have the right to visit as

long as my payments are regular.... (12) $26.1 \%$

2. I should have the right to visit if my payments are usually regular.... (7) 15.2

3. I should have the right to visit as long as I make some payments........ (1) 2.2

4. I should have the right to visit even if I seldom make payments...... (2) 4.3

5. I should have the right to visit even if I never make a payment..... (14) 30.4

6. I expect all the minor children to live with me................ (10) 21.7

54) What part should the court play in working out a visiting agreement? $\quad N=46$

2. none $\ldots \ldots \ldots \ldots \ldots \ldots \ldots \ldots \ldots$ (13) $28.3 \%$

leges and leave deta1ls to parents. (15) 32.6

3. provide counselors to help parents work out details of visiting

agreements................... (4) 8.7

4. provide counselors for parents if problems arise in visiting arrangements.................. (5) 10.9

5. spell out the detalls of visiting agreement after checking with the parents or their lawyers.......... (0)

6. spell out the detalls of visiting agreement after checking with the parents and their lawyers and see to it that the parents live up to the agreement................... (9) 19.5

55) Do you expect any problems in visiting the children? $N=49$

1. very few................. (35) $71.4 \%$

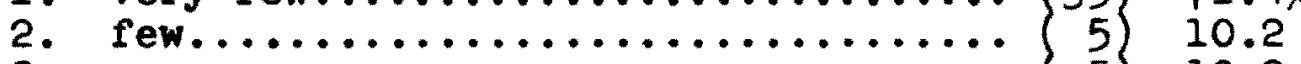

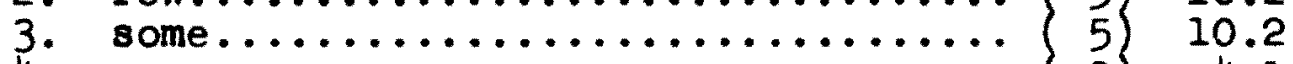

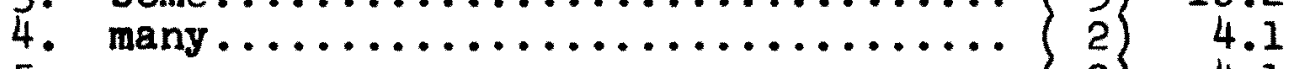

5 . very many $\ldots \ldots \ldots \ldots \ldots \ldots \ldots \ldots \ldots$ ( 2) 4.1 
56) What problems do you expect to have in arranging your visits with the children? You may mark more than one. $\quad \mathrm{N}=47$

2. live too far away.... too little money... $6\left(\begin{array}{l}6 \\ 3\end{array}\right)$

3. agreeing on visiting times........... (13) $\begin{array}{cccc}0 & 1 & 2 \text { or more } \\ 28 & 14 & 5\end{array}$

4. picking up and returning the children............. ( 5$)$

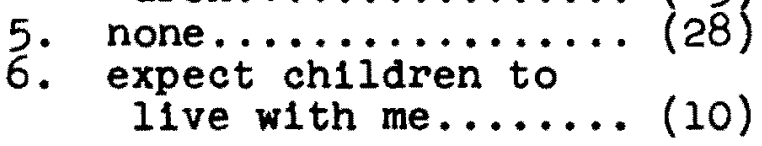

57) What problems do you expect to have while visiting the ch1ldren? You may mark more than one. $\quad \mathrm{N}=57$

1. where the visit takes

$$
\text { place............... }
$$

2. uncomfortable being with the children in a visiting situation...........

3. things for the children to do........... (5)

4. keeping the visits from becoming "just routine"!

5. none.

58) What problems do you expect to have with your wife's attitude about your visiting the children? You may mark more than one. $\quad \mathrm{N}=57$

1. about my drinking.... (2)

2. about my friendship with other women.... (4) \begin{tabular}{cccc}
0 & 1 & 2 or more \\
\hline 25 & 20 &
\end{tabular}

3. about my automobile $\frac{0}{40} \frac{1}{16} \quad 2$ or more

driving............ (1)

4. about religion........ (2)

5. about her questioning the children after a visit.......(10)

6. none............... (40) 
59) List all your chlldren from the present marrlage starting with the oldest: $\quad N=54$

F1rst Name

1.

2 .

3.

4.

5 .

6.

7 .

8.

Number of ch1ldren...... $\bar{X}=2.09$
Age Relationsh1p

( ) son ( ) daughter

() son ( ) daughter

( ) son ( ) daughter

( ) son ( ) daughter

( ) son ( ) daughter

( ) son ( ) daughter

( ) son ( ) daughter

( ) son ( ) daughter 
APPENDIX B

1. Letter From Judge Jean L. Lew1s to Divorcing Parents Explatining the Purpose of the Research

\author{
"Clrcult Court of Oregon \\ "Fourth Judiclal District - Dept. No. 12 \\ "County Courthouse \\ "Portland, Oregon 97204
}

"Jean L. Lew1s
"Judge

"Dear

"The Domest1c Relations Department of the C1rcult

Court for Multnomah County is concerned with the welfare of children of divorced parents. Of special interest to us are the ways parents are able to work out a visiting arrangement between minor chlidren and the parent who does not Ilve with them. Many of these programs work very well. Other families constantly have problems. Since it is our respons1bility to attempt to $f 1 x$ a visitation program that has meaning and value to the parties, we are interested in obtaining accurate information about what programs are successful and those that are not so that we might be of more assistance to other families in the future.

"We are cooperating with a research team from Portland State Unlversity, and I would appreclate your completing the enclosed questlonnalre in order to ald the researchers in gathering specific information.

"The information that is being requested is for research purposes only. Your reply will be strictly confidential. Your completed questionnalre will go directly to the research team and will not be used or made avallable to the court. Your answers to the questions w1ll not be seen by any Judge, attorney, or officer of the court. Your questionnalre w11l not be seen by your spouse.

"After the research workers have combined your answers with many others, general conclusions may be reached after several months of study. 
"As a parent, I am sure you are as concerned as I about helping children adjust to divorce. I am counting on your cooperation to answer the questionnalre accurately and to ma1l it in promptly.

"Yours very truly,

"JEAN L. LEWIS

"C1rcult Judge" 
APPENDIX B

2. Interviewer: Follow-up Phone Call Requesting That the Questionna1re Be Returned

I. Introduction

My name is - I am part of the Portland State Research Team working with Judge Lew1s.

II. Ask them to return it if they recelved 1t. Judge Lewis sent you a letter and questionnalre a few weeks ago. Did you recelve 1t? We haven't recelved it back and were wondering if you had any questions about 1t? (Answer any questions to the best of your ability and try to convince them to return the questionna1re.)

Judge Lew1s is most anxious to have these questionnalres returned as soon as possible so we can complete the research. Your answers are all strictly confidential and will not be seen by anyone other than the research team members.

We would appreclate it if you would fill out the questionna1re and return 1 t th1s week. Thank you so much. 
APPENDIX B

3. Follow-up Letter Requesting That The Quest IonnaIre Be Returned

MCA Research Team

School of Soclal Work

Portland State UnIversity

1632 s. W. 12th Ave.

Portland, Oregon 97201

Dear

A letter and questionnalre were recently malled to you from Judge Lewls regarding visitation of minor children after their parents file for divorce. The questionnalre was to be returned to the Portland State Unlversity research tean which is recording the results. We have not recelved your questionna1re. Judge Lew1s is most anxious to have these returned as soon as possible so that the team can complete the research.

As Judge Lew1s stated in her letter this information 1s strictly confidential and will not be seen by anyone but the research team. Please send yours in this week.

Thank you for your cooperation.

Sincerely yours,

Vincent Glaudin, Ph.D.

Director, MCA Research Team

VG:vc 
APPENDIX B

4. Interviewer: Phoning To Make Interview Appointment

I. Introduction

My name 18 - I am part of the Portland State Un1versity Research Team working with Judge Lew18. You fllled out a questionnalre a few weeks ago regarding visitation of minor children. We really appreciate your filling it out for us.

II. Asking them to come in for an appointment We understand that often 1 t $18 n$ 't enough to f1ll out a questionnalre and that it is much more helpful to talk to someone in person. Therefore, we're asking everyone who filled out a questionnalre to come in for an interview. Like the questionnalre, it will be strictly confidential. We certainly would appreclate it if you could come in. (Arrange a time.)

Thank you so much. I'm looking forward to seelng you then. 
APPENDIX B

5. Interviewer: At Beginning of Interview

I. Introduction

Hello, I'm - Won't you come in?

II. Small Talk to Put Interviewee at Ease

I hope you didn't have too much trouble finding this office, etc.

III. Explanation of Interview

You might have some questions about why I asked you here. (Pause - answer any questions.) As I sald on the phone, we realize that a written questionnalre is often inadequate to really know a person, and we would like to hear In your own words the responses to our questions. Furthermore, you may be able to help us by adding things that are Important or telling us where questions are unclear. Having gone through th1s experience yourself, you know better than we do what is important.

Also, we're checking on the clarity of the questionnalre and not on your consistency. There may be answers that you want to change. Please feel free to do so. If the s1tuation has changed significantly in any way since you filled out the questionnalre it would help if you point that out. 
I haven't seen your original questionnalre, so I don't know how you answered the questions the first time. The interviewers do not see any of the questionnaires before we interview.

Do you have any questions? If not, let's begin. I'd like you to help me fill this out.

IV. At Conclusion

Is there anything else you'd like to add or discuss? Thank you so much for coming in. You have been most helpful and we really appreclate $1 t$. 
Number, Percentage, and Correlation of Response Agreement Between Malled-in Questionnalres and the 30 Interviews

No. of

Question Question

4.

5 .

6.

7 .

8.

9.

12.

13.

14.

15.

16.

17.

18.

Age

Race

Religion before?
Number

of

Agreement

30

30

29

30

Percentage

of

Agreement $r$

100

100

97

100

How long have you lived at your current address?

Please indicate the amount of schooling you have completed:

26

87

Are you presently

employed?

28

93

How long have you worked for your present or most recent employer?

28

97

What is your income?

22

73

How long have you been marrled to your present wife (husband)?

30

100

How old were you when you married your present wife (husband)?

29

97

Have you been married

30

100

How long have you been separated from your present wife (husband)?

Have you been separated before? 
No. of

Question Quest1on

19. How long ago did you

and your wife (husband) first talk about getting a divorce?

20.

21.

22.

23.

24.

Who flled for this

divorce?

Who wants a divorce more? 28

Do you want to reconc1le? 25

Do you belleve your wife (husband) wants to reconclle?

If a divorce 18 granted, do you think you w111 be getting married to someone else during the coming year?

27

90

25.

If a divorce is granted, do you think your wife (husband) w111 be getting married to someone else during the coming year?

21

70

28.

Have you ever had a nervous breakdown?

27

90

29.

Have you ever felt you

were going to have a

nervous breakdown?

25

83

30.

Has your wife (husband)

ever had a nervous

breakdown?

28

93

31.
Have you ever wanted your

wife (husband) to be pun1shed?
83

23

77

Percentage

50

97

93

Agreement Agreement $r$ 
No. of

Question Question

32 .

33.

34.

35.

37.

38.

39.

40.

41.

\begin{tabular}{ll} 
Number & Percentage \\
of & of \\
Agreement & Agreement $\quad r$ \\
\hline
\end{tabular}

19

63 .55

22 wife (husband)?

53 .46

53 .55

26

87

Have you and your wife (husband) reached an agreement about visiting your children?

20

67 .28

Are any of your minor chlldren ( 18 and under) living with you now?

29

97

At present, when the children are not in school, does anyone help take care of them in add1tion to the parents?

If a divorce is granted, where do you expect the children to live? 
No. of

Question Question
Number

of

Agreement Agreement $r$

42. If a divorce $1 \mathrm{~s}$ granted, do you expect your wife (husband) to work for pay outside the home?

22

43.

How frequently have you (has your husband) visited the children during the separation?

44.

During your separation, what has been the effect of your (husband's) visiting the children?

45.

During your separation, what are the children's feelings toward you (your husband)?

46.

How frequently do you expect (your husband) to v1s1t the children in the future?

47.

Do you think your wife wants you (Do you want your husband) to visit the children?

24

80

48.

When do you expect (your husband) to visit the ch1ldren in the future? $21 \quad 70$

49. What arrangement should be made for your (husband's) visits?

50 .

At what age do you think a child should help make the main decisions about visiting with you (your husband)? 
No. of

Question Question

51. How 1mportant do you

feel it is for you

(your husband) to visit

the children in the

future?

52.

What do you belleve is

the most important purpose of your (husband's) visiting the children?

13

43

53.

What is the connection between your (husband's) paying child support and visiting the children?

20

67

54.

What part should the court play in working out a visiting agreement?

55.

Do you expect any problem s with (your husband's) visiting the children?
Percentage of of $\quad$ of Agreement Agreement $r$
21

70 .39 